\title{
Relationship between daily atmospheric circulation patterns and South Atlantic Convergence Zone (SACZ) events
}

\author{
Gustavo Carlos Juan ESCOBAR ${ }^{1 *}$ and Michelle SIMÕES REBOITA ${ }^{2}$ \\ ${ }^{1}$ Coordenação-Geral de Ciências da Terra (CGT), Instituto Nacional de Pesquisas Espaciais (INPE), Rodovia Dutra \\ km 39, 12630-000, Cachoeira Paulista, SP, Brasil. \\ ${ }^{2}$ Instituto de Recursos Naturais, Universidade Federal de Itajubá, Av. BPS, 1303, Itajubá, Minas Gerais, MG, 37500- \\ 903, Brasil. \\ *Corresponding author: gustavo.escobar@inpe.br
}

Received: June 30, 2020; accepted: October 8, 2020

\begin{abstract}
RESUMEN
Este trabajo presenta los patrones diarios de circulación atmosférica en superficie y en altura relacionados con los eventos de la Zona de Convergencia del Atlántico Sur (ZCAS) ocurridos entre 2007 y 2017. Para ello se utilizaron el análisis de patrones de secuencias principales (APSP) y datos de reanálisis de presión a nivel medio del mar y de altura geopotencial. Se identificaron cuatro patrones típicos de circulación atmosférica asociados con episodios de la ZCAS. Tres de ellos están relacionados con la propagación de un frente frío hacia el sureste de Brasil con un anticiclón postfrontal que se mueve sobre el Océano Atlántico. El cuarto patrón está asociado con la presencia de una baja segregada centrada sobre la región centro-sur de Brasil que induce el transporte de humedad desde el Océano Atlántico y desde la cuenca del Amazonas hacia gran parte del sureste de Brasil. Los tres primeros patrones representan, respectivamente, una onda frontal, un frente frío clásico y un frente frío con un lento desplazamiento. Todos estos patrones producen vientos persistentes del noroeste en la troposfera baja sobre el sureste de Brasil desde dos días antes de la ocurrencia de eventos de la ZCAS.
\end{abstract}

\begin{abstract}
This study presents the daily atmospheric circulation patterns at surface and altitude related to the South Atlantic Convergence Zone (SACZ) events that occurred between 2007 and 2017. For this analysis, Principal Pattern Sequence Analysis (PPSA) and sea level pressure and geopotential height reanalysis were used. Four typical atmospheric circulation patterns associated with SACZ episodes were identified. Three of them are related to the propagation of a cold front toward southeastern Brazil with a post-frontal anticyclone moving over the Atlantic Ocean. The fourth pattern is associated with the presence of a cut-off low centered over the central-south region of Brazil that induces moisture transport from the Atlantic Ocean and from the Amazon basin to most of southeastern Brazil. Considering the first three patterns, they represent, respectively, a frontal wave, a classical cold front, and a slow-moving cold front. All of these patterns provide permanent northwesterly winds in the lower troposphere over southeastern Brazil from two days before the SACZ occurrence.
\end{abstract}

Keywords: synoptic variability, classification, SACZ. 


\section{Introduction}

The South Atlantic Convergence Zone (SACZ) is characterized by a persistent cloud band oriented northwest-southeast, extending from the Amazon basin to the southwest Atlantic Ocean (Kousky, 1988; Kodama, 1992; Quadro, 1994; Carvalho et al., 2004; Silva et al., 2019). The SACZ is one of the most important meteorological systems over South America during the summer since it influences the characteristics of the rainy season in most of Brazil (Nogués-Peagle and Mo, 1997). This system develops between October and April, changing precipitation over the north, central-west, and southeast regions of Brazil. In this period of the year, most of the area influenced by the SACZ is affected by intense and persistent rains that cause strong impacts on the human population through landslides and floods (Seluchi and Chou, 2009; Escobar, 2014; Reboita et al., 2017; Brasiliense et al., 2018), especially where there is a higher population concentration (Satyamurty et al., 1998).

In the last decades, there has been considerable progress in knowledge about the leading role of the SACZ in the monsoon system of South America (Nogués-Paegle and Mo, 1997, 2002; Vera et al., 2006; Reboita et al., 2010a; Marengo et al., 2012; Costa and Satyamurty, 2016). More recently, Satyamurty and Rosa (2020) described the seasonal variations of the SACZ by means of a synoptic climatology produced with satellite images. However, weather forecasters have faced many difficulties related to the SACZ identification in the daily routine of the different operational weather centers of Brazil. For example, during the rainy season in Brazil, the weather forecasters observe meteorological situations that seem to be a development of a SACZ episode; however, they evolve into a typical summer meteorological situation (showers, most of the time accompanied by lightning and thunders), where the organized cloudiness responds only to thermodynamic processes (they do not have dynamic influence).

The mean synoptic pattern associated with SACZ episodes is related to the presence of a stationary frontal system at surface over the Atlantic Ocean, close to the southeast region of Brazil, which contributes to the initiation of the moisture convergence at low levels (Escobar and Seluchi, 2012; Escobar, 2014). In the upper troposphere, the mean atmospheric cir- culation pattern is associated with the presence of the Bolivian High (BH) (Lenters and Cook, 1997) and the cyclonic vortex at high levels near northeastern Brazil (CVHL-NB) (Kousky and Gan, 1981). The convective precipitation observed in much of the central-west, southeast and north regions of Brazil during the rainy season contributes to maintaining the substantial divergence at high levels produced by the $\mathrm{BH}$. Once these surface and altitude atmospheric circulation patterns are established, the transient systems at surface continue passing south of the $30^{\circ} \mathrm{S}$ latitude. In this way, the atmospheric circulation pattern associated with SACZ episodes remains active and persists approximately between three and 10 days (Escobar and Matoso, 2018).

Escobar (2019) performed a synoptic classification during the Brazilian rainy season for 1979-2016, considering SACZ days and no-SACZ days. This author identified four main synoptic patterns in which two of the most frequent patterns were associated with SACZ events and the climatological mean-field, respectively. The other two synoptic patterns were related to a cold front in the south and southeast regions of Brazil, respectively.

The cold fronts and the baroclinic troughs (Escobar et al., 2019) are the main meteorological systems identified in the daily weather types during the Brazilian rainy season. In this period, the cold fronts are more oceanic and present greater zonal displacement (Andrade, 2005). In addition, the presence of cyclones that form over the Atlantic Ocean is also observed, especially between the Brazilian states of Santa Catarina (SC) and Espírito Santo (ES) (Taljaard, 1972; Simmonds and Keay, 2000; Hoskins and Hodges, 2005; Reboita et al., 2010b; Gozzo et al., 2014; Rocha et al., 2019; Rosa et al., 2019). The atmospheric circulation associated with the cyclones maintains the moisture convergence at low levels and, consequently, contributes to the intensification of precipitation. Most of these cyclones show extratropical characteristics and sometimes they may present subtropical (Evans and Braun, 2012; Gozzo et al., 2014; Brasiliense et al., 2018) or tropical (McTaggart-Cowan et al., 2006) characteristics. On several occasions, these cyclones are also associated with SACZ episodes (Escobar and Seluchi, 2012; Escobar, 2014; Silva et al., 2019), causing strong impacts on the human population (Brasiliense et al., 2018). 
The North-Western Argentinean Low (NAL) and the Chaco Low (CHL) are two of the most characteristic systems of low-level atmospheric circulation in South America, having a relevant role during the rainy season in Brazil (Seluchi and Marengo, 2000; Seluchi et al., 2003; Escobar and Seluchi, 2012; Marengo et al., 2012). The CHL has a shallow warm core and is located approximately between the north of Argentina, Paraguay, south of Bolivia and the south of Mato Grosso do Sul (MS). The NAL is usually located around $30^{\circ} \mathrm{S}$ to the leeward side of the Andes mountains. It presents a shallow warm core and orographic features and occasionally is influenced by dynamic processes. Escobar and Seluchi (2012) performed a synoptic classification of surface pressure fields and found that in the summer season both NAL and CHL can appear in meteorological conditions related to SACZ episodes.

Some studies have shown synoptic features of the atmosphere during SACZ events and the impacts of SACZ on precipitation. Seluchi and Chou (2009) found that the heavy rainfall episodes associated with landslide events in the southeast coastal mountain region of Brazil were mostly related to cold front passages and the SACZ. The most common synoptic pattern associated with this system showed a blocking configuration with a northwest to southeast oriented inverted trough over the Atlantic Ocean, close to the coast of São Paulo (SP) state. They also found that the South Atlantic Subtropical Anticyclone (SASA) was displaced to the south of its climatological position, and the CHL was located over western Brazil and Paraguay. A similar synoptic pattern was found by Weide-Moura et al. (2013) when they made a synoptic classification related to heavy rainfall in Rio de Janeiro city (RJ).

Escobar (2014) carried out a classification of atmospheric circulation fields at the surface and 500 $\mathrm{hPa}$ associated with intense rainfall over most part of Minas Gerais (MG) state during December 2011. The SACZ episode associated with a "dipole" blocking configuration over the Atlantic Ocean was the synoptic pattern responsible for this severe weather event. A similar atmospheric circulation pattern related to a SACZ event was found by Brasiliense et al. (2018) in their study of the synoptic situation associated with an intense rainfall event in the Paraíba do Sul river basin in the southeast region of Brazil during
January 2000. A blocking pattern was configured over the Atlantic Ocean with a subtropical cyclone at the surface that contributes to intensifying the moisture flux convergence from the Amazon basin and tropical South Atlantic toward southeastern Brazil.

In summary, concerning the daily analysis of the weather, it is possible to identify more than one synoptic pattern associated with SACZ episodes. Due to this daily variability in the synoptic patterns of the SACZ, the objective of this study is to identify the principal modes of daily variation of the atmospheric circulation in the whole troposphere associated with the beginning of the SACZ episodes. In other words, we have a dataset of SACZ episodes from 2007 to 2017 and we reduced it to a small number of atmospheric patterns that represent the total sample of data. The main synoptic patterns of SACZ obtained in this work may also help the weather forecasters to improve the forecast of severe weather episodes during the Brazilian rainy season.

\section{Data and methodology}

\subsection{Data}

Sea level pressure (SLP) and the geopotential height fields on 850, 500 and $250 \mathrm{hPa}$ levels at 12:00 UTC from the National Center for Environmental Prediction (NCEP) Climate Forecast System Reanalysis (CFSR) (Saha et al., 2010, 2014) are used for 20072017. These data are available at a spatial resolution of $0.5^{\circ} \times 0.5^{\circ}$ longitude. The area under study is bounded between $5^{\circ}-40^{\circ} \mathrm{S}, 30^{\circ}-80^{\circ} \mathrm{W}$, and the period includes October through April (rainy season in South America) (Fig. 1).

\subsection{Detection of SACZ episodes}

To identify the principal modes of daily variation of the atmospheric circulation at surface and in the upper air associated with the beginning of the SACZ episodes, firstly, it is necessary to identify these episodes. Then, the SACZ episodes were identified by analyzing the surface and upper synoptic charts at 12:00 UTC from October 2006 to April 2017, performed by the weather forecasters from the CPTEC/ INPE. The dates of SACZ events were selected using the methodology presented by Escobar and Matoso (2018), in which the following characteristics should appear simultaneously in the synoptic charts: 
a. A cold front or a baroclinic trough located over the ocean, near the coast between SP and ES states.

b. A trough in the middle $(500 \mathrm{hPa})$ and high troposphere $(250 \mathrm{hPa})$ located over the southeast region of Brazil or the southern part of the northeast region of Brazil.

c. A polar jet stream $(250 \mathrm{hPa})$ coupled with a subtropical jet stream associated with the cold front at the surface.

c. A subtropical jet stream associated with the baroclinic trough at the surface.

e. A horizontal equivalent potential temperature gradient at $850 \mathrm{hPa}$, pointing from the Atlantic Ocean to the continent.

f. A northwesterly flow at $850 \mathrm{hPa}$ extending from the Amazon region to the Atlantic Ocean, passing through the central-west and southeast regions of Brazil.

g. A homogeneous region where the upward motion at $500 \mathrm{hPa}$ is in phase with the convergent flow at $850 \mathrm{hPa}$, and the total precipitable water values are greater than $45 \mathrm{~mm}$.

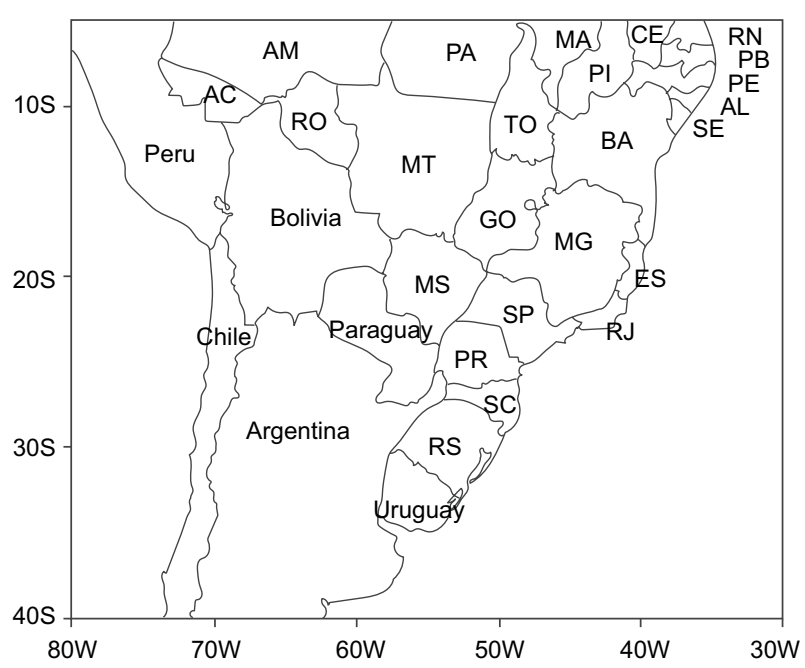

Fig. 1. Map of South America with Brazil's states abbreviations. RS: Rio Grande do Sul, SC: Santa Catarina, PR: Paraná, SP: São Paulo, RJ: Rio de Janeiro, ES: Espírito Santo, MG: Minas Gerais, MS: Mato Grosso do Sul, MT: Mato Grosso, GO: Goiás, BA: Bahia, SE: Sergipe, AL: Alagoas, PE: Pernambuco, PB: Paraíba, RN: Rio Grande do Norte, CE: Ceará, PI: Piauí, MA: Maranhão, TO: Tocantins, PA: Pará, AM: Amazonas, AC: Acre, RO: Rondônia. h. A low-level convergence zone and a band of cloudiness persisting for at least three consecutive days.

The SACZ episodes selected with this methodology are presented in Table I.

\subsection{Classification of SACZ events}

Using the criteria for detecting SACZ episodes (section 2.2), 109 cases were identified for the period 2007-2017. For these events, the main atmospheric circulation patterns at surface and 850, 500, and $250 \mathrm{hPa}$ were identified through Principal Pattern Sequence Analysis (PPSA) (Compagnucci et al., 2001; Escobar et al., 2004; Huth et al., 2008). According to Compagnucci et al. (2001), the PPSA is considered an extension of the traditional Principal Component Analysis (PCA), with a correlation matrix in T-mode (Green and Carrol, 1978; Richman, 1986; Escobar et al., 2016), whose main objective is to obtain the evolution of the principal dominant modes of atmospheric circulation for specific meteorological situations. Thus, in this application, each variable is a sequence of the consecutive spatial field of a given meteorological variable, and observations correspond to grid points. In this way, the T-mode allows identifying subgroups or types of fields with the same spatial structure.

The matrices have $109 \times 7171$ (cases $\times$ variables) for two days before the SACZ (day 2), one day before the SACZ (day 1), and the SACZ day (day 0). Therefore, the cases correspond to days (109), and variables are the selected grid points over the used domain (7171). The final matrix used as input for the PPSA consists of $109 \times 21513$ (days $\times$ grid points), and it was composed of the three single matrices arranged one below the other. The PPSA was undertaken separately for each meteorological field (SLP and geopotential height at 850, 500, and $250 \mathrm{hPa}$ ).

After the application of the PPSA, the Varimax rotation (Richman, 1986) was performed. This methodology is useful to redistribute the total variance of the data among the components to emphasize the physical meaning of the Principal Pattern Sequence (PPS) generated (Richman, 1986). The results and the variance explained by the PPSs depend on the number of sequences retained in rotated solutions. There is no single method acceptable to 
Table I. Start and end dates (month/date/year) of the $109 \mathrm{SACZ}$ episodes that occurred over Brazil from October 2006 to April 2017.

\begin{tabular}{|c|c|c|}
\hline $10 / 17 / 2006-10 / 20 / 2006$ & $01 / 21 / 2010-01 / 23 / 2010$ & $12 / 12 / 2013-12 / 26 / 2013$ \\
\hline $11 / 10 / 2006-11 / 12 / 2006$ & $03 / 01 / 2010-03 / 12 / 2010$ & $01 / 17 / 2014-01 / 20 / 2014$ \\
\hline $11 / 29 / 2006-12 / 01 / 2006$ & $03 / 28 / 2010-03 / 31 / 2010$ & $02 / 15 / 2014-02 / 19 / 2014$ \\
\hline $12 / 08 / 2006-12 / 16 / 2006$ & $10 / 19 / 2010-10 / 21 / 2010$ & $02 / 28 / 2014-03 / 02 / 2014$ \\
\hline $12 / 27 / 2006-12 / 29 / 2006$ & $10 / 27 / 2010-10 / 29 / 2010$ & 03/06/2014-03/10/2014 \\
\hline $01 / 21 / 2007-01 / 25 / 2007$ & $11 / 01 / 2010-11 / 04 / 2010$ & $03 / 22 / 2014-03 / 24 / 2014$ \\
\hline $01 / 30 / 2007-02 / 05 / 2007$ & $12 / 01 / 2010-12 / 04 / 2010$ & $10 / 26 / 2014-10 / 29 / 2014$ \\
\hline $02 / 12 / 2007-02 / 16 / 2007$ & $12 / 14 / 2010-12 / 18 / 2010$ & $11 / 15 / 2014-11 / 19 / 2014$ \\
\hline $03 / 19 / 2007-03 / 22 / 2007$ & $12 / 27 / 2010-01 / 07 / 2011$ & $11 / 27 / 2014-11 / 30 / 2014$ \\
\hline $10 / 23 / 2007-10 / 25 / 2007$ & $01 / 11 / 2011-01 / 20 / 2011$ & $12 / 14 / 2014-12 / 17 / 2014$ \\
\hline $11 / 04 / 2007-11 / 06 / 2007$ & 02/15/2011-02/17/2011 & $12 / 24 / 2014-12 / 26 / 2014$ \\
\hline $11 / 27 / 2007-12 / 02 / 2007$ & 02/28/2011-03/10/2011 & $01 / 22 / 2015-24 / 01 / 2015$ \\
\hline $12 / 12 / 2007-12 / 15 / 2007$ & 04/04/2011-04/07/2011 & $02 / 05 / 2015-02 / 09 / 2015$ \\
\hline $12 / 19 / 2007-12 / 23 / 2007$ & $10 / 02 / 2011-10 / 07 / 2011$ & $02 / 16 / 2015-02 / 19 / 2015$ \\
\hline 01/06/2008-01/11/2008 & 10/16/2011-10/20/2011 & $02 / 27 / 2015-03 / 01 / 2015$ \\
\hline 01/20/2008-01/23/2008 & $11 / 01 / 2011-11 / 04 / 2011$ & $03 / 09 / 2015-03 / 14 / 2015$ \\
\hline 01/30/2008-02/02/2008 & 11/23/2011-12/05/2011 & $03 / 17 / 2015-03 / 20 / 2015$ \\
\hline $02 / 03 / 2008-02 / 08 / 2008$ & $12 / 09 / 2011-12 / 12 / 2011$ & $03 / 22 / 2015-03 / 25 / 2015$ \\
\hline 02/24/2008-03/08/2008 & $12 / 15 / 2011-12 / 22 / 2011$ & $04 / 06 / 2015-04 / 08 / 2015$ \\
\hline 03/13/2008-03/18/2008 & $12 / 26 / 2011-12 / 30 / 2011$ & $10 / 28 / 2015-10 / 30 / 2015$ \\
\hline $10 / 19 / 2008-10 / 21 / 2008$ & 01/01/2012-01/09/2012 & $01 / 14 / 2016-01 / 19 / 2016$ \\
\hline $11 / 07 / 2008-11 / 09 / 2008$ & $01 / 15 / 2012-01 / 21 / 2012$ & $01 / 20 / 2016-01 / 23 / 2016$ \\
\hline $11 / 13 / 2008-11 / 24 / 2008$ & $01 / 26 / 2012-01 / 31 / 2012$ & $02 / 29 / 2016-03 / 05 / 2016$ \\
\hline $12 / 03 / 2008-12 / 06 / 2008$ & $02 / 11 / 2012-02 / 13 / 2012$ & 03/10/2016-03/14/2016 \\
\hline $12 / 12 / 2008-12 / 21 / 2008$ & $03 / 16 / 2012-03 / 21 / 2012$ & $03 / 24 / 2016-03 / 27 / 2016$ \\
\hline $12 / 25 / 2008-12 / 31 / 2008$ & $03 / 24 / 2012-03 / 26 / 2012$ & $10 / 05 / 2016-10 / 09 / 2016$ \\
\hline 01/04/2009-01/09/2009 & $11 / 04 / 2012-11 / 08 / 2012$ & $11 / 15 / 2016-11 / 19 / 2016$ \\
\hline 01/21/2009-01/23/2009 & $11 / 14 / 2012-11 / 22 / 2012$ & $12 / 03 / 2016-12 / 06 / 2016$ \\
\hline 01/29/2009-01/31/2009 & $11 / 26 / 2012-11 / 28 / 2012$ & $12 / 14 / 2016-12 / 16 / 2016$ \\
\hline 02/12/2009-02/15/2009 & $12 / 15 / 2012-12 / 17 / 2012$ & $01 / 13 / 2017-01 / 15 / 2017$ \\
\hline 03/13/2009-03/17/2009 & 01/09/2013-01/17/2013 & $01 / 18 / 2017-01 / 23 / 2017$ \\
\hline 03/25/2009-04/02/2009 & $01 / 26 / 2013-01 / 30 / 2013$ & $01 / 26 / 2017-01 / 28 / 2017$ \\
\hline 04/08/2009-04/11/2009 & $02 / 04 / 2013-02 / 10 / 2013$ & $02 / 08 / 2017-02 / 10 / 2017$ \\
\hline $10 / 08 / 2009-10 / 12 / 2009$ & $02 / 27 / 2013-03 / 04 / 2013$ & $02 / 25 / 2017-02 / 28 / 2017$ \\
\hline $10 / 28 / 2009-11 / 01 / 2009$ & $03 / 27 / 2013-03 / 30 / 2013$ & 03/29/2017-04/03/2017 \\
\hline $12 / 04 / 2009-12 / 09 / 2009$ & $10 / 18 / 2013-10 / 20 / 2013$ & \\
\hline $12 / 13 / 2009-12 / 15 / 2009$ & $11 / 05 / 2013-11 / 09 / 2013$ & \\
\hline
\end{tabular}

define the optimum number of significant PPSs (Preisendorfer et al., 1981; Joliffe, 1986; Richman, 1986; Richman et al., 1992). In this study, a set of rules to decide on the number of retained PPSs was used: $(a)$ the eigenvalue 1.0 rule (Kaiser, 1958); (b) the LEV (log-eigenvalues) diagram (Craddock and Flood, 1969), and (c) additional physical interpretation. The results showed, for all the analyzed levels, that the number of significant retained PPS represented a cumulative percentage of explained variance greater than $75 \%$.
The number of PPSs retained for each variable, and the corresponding percentages of variance and the cumulative percentages that were explained are shown in Table II. The resulting PPSs are dimensionless fields, while PPSs loadings are time series of correlations between PPSs and real meteorological fields (atmospheric circulation at surface and geopotential height at 850,500 , and $250 \mathrm{hPa}$ ) (Richman, 1986). The component loadings analysis allows the evaluation of the representative patterns (obtained from PPSA) as real atmospheric circulation fields 
Table II. Percentages of explained variance and the cumulative percentages explained by the PPSs retained for each meteorological variable.

\begin{tabular}{crrrrrrrr}
\hline \multirow{2}{*}{ PPS } & \multicolumn{2}{c}{ SLP } & \multicolumn{2}{c}{$850 \mathrm{hPa}$} & \multicolumn{2}{c}{$500 \mathrm{hPa}$} & \multicolumn{2}{c}{$250 \mathrm{hPa}$} \\
\cline { 2 - 8 } & P. Var. & P.C. Var. & P. Var. & P.C. Var. & P. Var. & P.C. Var. & P. Var. & P.C. Var. \\
\hline 1 & 18.2 & 18.2 & 26.1 & 26.1 & 29.1 & 29.1 & 30.3 & 30.3 \\
2 & 17.1 & 35.3 & 12.5 & 38.6 & 26.0 & 55.1 & 29.2 & 59.5 \\
3 & 15.5 & 50.8 & 11.2 & 49.8 & 15.9 & 71.0 & 18.8 & 78.3 \\
4 & 8.3 & 59.1 & 11.1 & 60.9 & 14.6 & 85.6 & 13.1 & 91.4 \\
5 & 7.9 & 67.0 & 6.7 & 67.6 & 4.0 & 89.6 & 1.6 & 93.0 \\
6 & 5.5 & 72.5 & 5.0 & 72.6 & 2.0 & 91.6 & & \\
7 & 5.1 & 77.6 & 3.9 & 76.5 & & & & \\
8 & 2.8 & 80.4 & & & & & & \\
\hline
\end{tabular}

P. Var.: explained variance; P.C. Var.: cumulative percentages.

(registered in the reanalyses). Values of component loadings closer to 1 represent sequences of atmospheric circulation fields similar to the obtained pattern sequence. Conversely, loadings with values closer to 0 represent sequences of atmospheric circulation fields without significant physical meaning (Harman, 1976; Cattell, 1978).

The spatial field of the PPSs can be interpreted in both their positive and negative phases (Compagnucci and Salles, 1997). PPSs are related to two different synoptic patterns that have the same shape. For positive values of component loadings (direct mode), PPSs have the same sign as the meteorological variable under study. For example, positive (negative) values of geopotential height at $500 \mathrm{hPa}$, represent high (low) heights in the PPSs. Conversely, for negative values of component loadings (indirect mode), PPSs have the opposite sign as the real meteorological fields. Therefore, positive (negative) values represent low (high) heights. In this study, the values of component loadings (figures not shown) were positive for all meteorological variables used. It means that the PPSs have the same sign as the meteorological fields (weather type).

To study the atmospheric circulation variability of the whole troposphere related to SACZ episodes, the PPSs of the different levels were related. First of all, a subjective procedure was performed through a visual examination of the PPS obtained at each level analyzed. Because most of the synoptic systems associated with SACZ events show a baroclinic vertical structure (Seluchi and Chou, 2009; Escobar, 2019), we could rapidly find the correspondences between the different levels, due to the personal experience in weather forecasting.

Finally, an objective procedure based on the correlation between the series of component loadings of each PPS identified at each level (figures not shown) was applied to confirm the visual examination results. We would like to highlight that the results are presented in terms of mean sea level pressure and geopotential height and that these fields reveal the atmospheric circulation pattern. Therefore, we can refer, for example, flow without showing the wind field. Moreover, when someone needs to do a synoptic analysis (charts showing only sea level pressure) and describes the principal synoptic weather systems, it is very common to use the term 'circulation' to identify the direction of the wind.

\section{Results}

The dates of the $109 \mathrm{SACZ}$ episodes identified from October 2006 to April 2017 are listed in Table I. The SACZ events (Fig. 2) showed a higher frequency during December and January (20\%) and lower in April (3\%).

Table II shows that the number of PPSs obtained at upper levels is smaller than at lower levels (the total variance is represented with a smaller number of PPSs than at lower levels). For example, at 250 $\mathrm{hPa}$, only three PPS represented $78.3 \%$ of the total variance, while at the surface, seven PPS were needed (Table II). The physical significance of fewer modes 


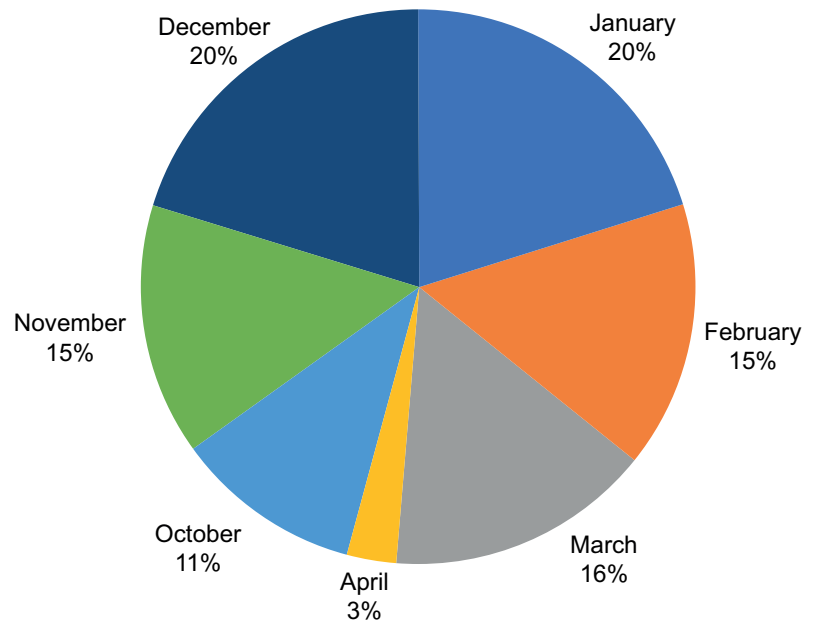

Fig. 2. Monthly percentages of SACZ events from 2007 to 2017.

explaining a large part of the total variance at upper levels is that the fields there are smoother, away from the surface irregularities.

\subsection{Geopotential height at $250 \mathrm{hPa}$}

The analysis identified five PPSs that explain $93.0 \%$ of the total variance, with the first four PPSs representing $91.4 \%$ of this total (Table II). The last PPS was not presented because it explained only $1.6 \%$ of the total variance. The four PPSs are shown in Figure 3, and each one (Fig. 3a-d) is composed by three frames, corresponding to day 2 in the left, day 1 in the middle, and day 0 (related to the day of SACZ occurrence) in the right.

PPS1 (Fig. 3a) explains $30.3 \%$ of the total variance and shows at day 2 a long-wave trough with its axis extending meridionally from the southern part of Argentina to northern Chile. Ahead of this low-pressure system, there is a long-wave ridge with an axis extending southeastward from subtropical latitudes to the south Atlantic Ocean. There is another trough positioned farther east of northeastern Brazil with its axis also extending southeastward from tropical latitudes to the Atlantic Ocean. In the following days, the atmospheric circulation appears practically stationary with the meteorological systems showing only a slight movement toward the east. The ridge amplifies slightly on day 1 over the Atlantic Ocean and appears on the SACZ day (day 0 ), located approximately at $27^{\circ} \mathrm{S}, 45^{\circ} \mathrm{W}$. This upper-level high-pressure system is usually associated with the position of the SASA at the surface (Escobar, 2019). As SASA is a dynamic system, it can be identified in the whole troposphere and the ridge or the anticyclone at $250 \mathrm{hPa}$ is located slightly to the west concerning its position near the surface. The trough located to the east of the Northeast region of Brazil is commonly related to CVHL-NB that acts during the rainy season (Kousky and Gan, 1981). The upper-tropospheric trough over Chile and western Argentina shows an intense horizontal geopotential height gradient, probably associated with a baroclinic surface zone.

PPS2 (Fig. 3b) explains $29.2 \%$ of the total variance and shows at day 2 a large area of low-pressure over the Atlantic Ocean centered at $37^{\circ} \mathrm{S}, 38^{\circ} \mathrm{W}$. This upper-level low-pressure system is associated with a trough with its axis extending southeastward from the east of the south region of Brazil to the south of the Atlantic Ocean. There is a ridge in the continent behind this trough with an associated high-pressure system located over the central and southern regions of Argentina. Both upper-level systems (the trough and the ridge) slowly move eastward during the subsequent days and are commonly associated with a slow displacement of a cold front with its associated post-frontal anticyclone at the surface.

PPS3 (Fig. 3c), with $18.8 \%$ of the total variance, is associated with the displacement of a trough from Argentina on day 2 to the Atlantic Ocean off the south region of Brazil during the day the SACZ is configured (day 0). Behind the trough, there is a wide high-pressure area centered approximately over northwestern Argentina and central Chile, which also covers a significant part of the south and central-west regions of Brazil. This upper-level high-pressure system is usually associated with the Bolivian High $(\mathrm{BH})$ that acts in this geographical region during Brazil's rainy season (Lenters and Cook, 1997). In this PPS, the presence of a second low-pressure system, located approximately to the east of Bahia (BA) state and affecting a large part of the Northeast region of Brazil, suggests the presence of the CVHL-NB.

Finally, PPS4 (Fig. 3d) explains $13.1 \%$ of the total variance. It shows at day 2 a large area of low-pressure centered over Uruguay and covering a great part of southern Brazil, the northeastern part of Argentina, and the southern part of Paraguay. During 

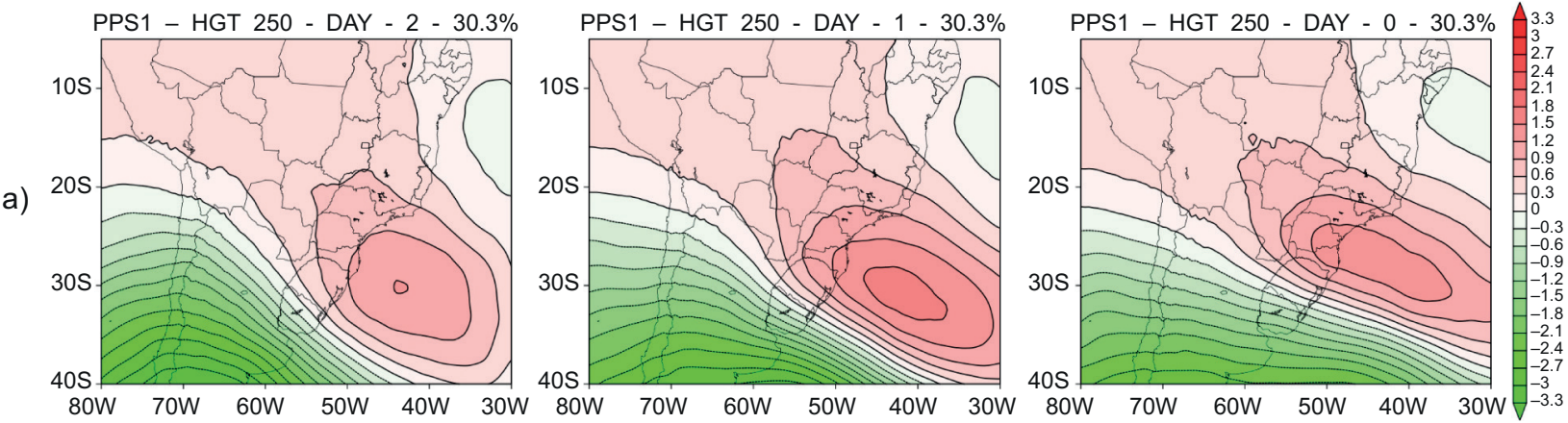

b)
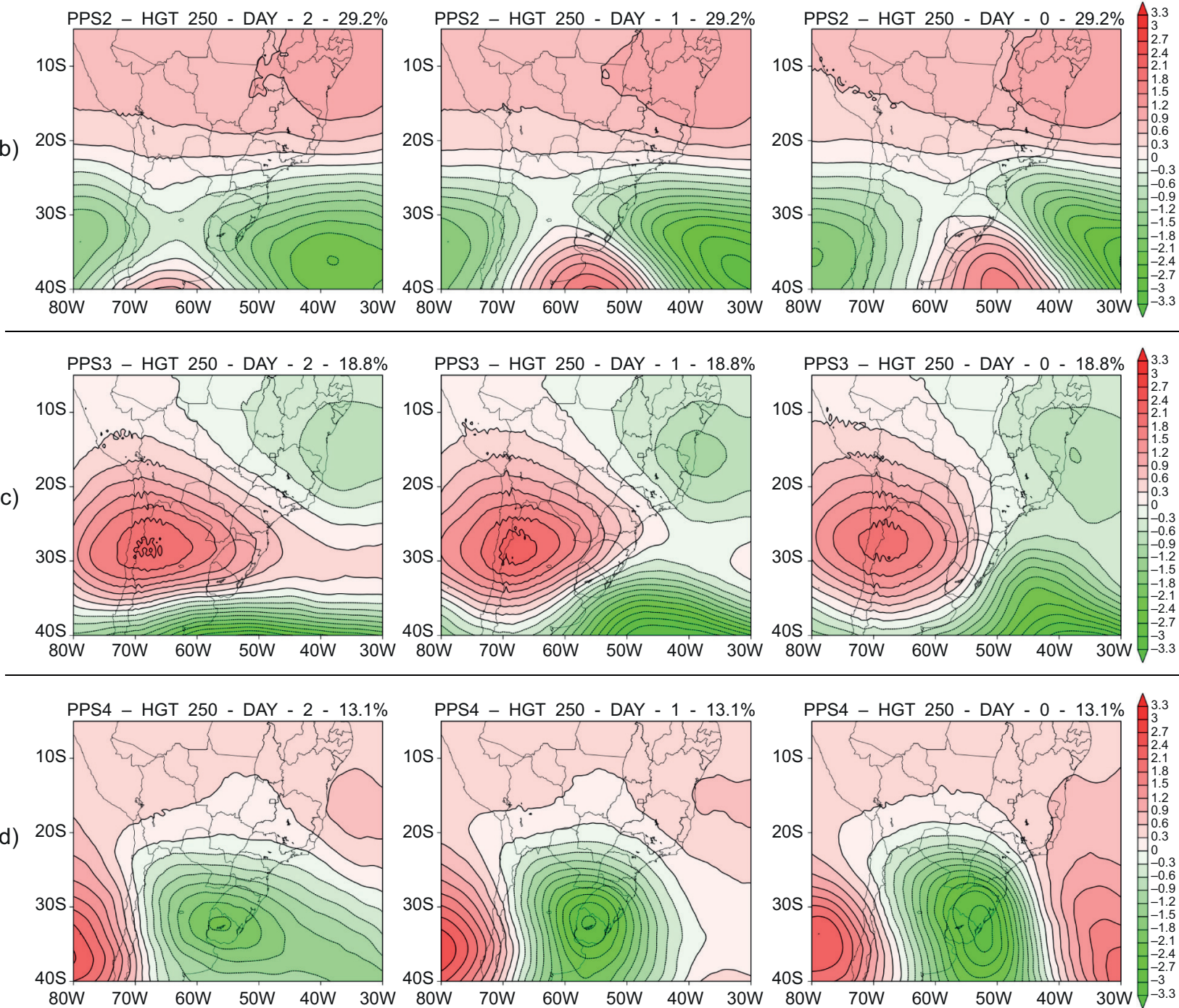

Fig. 3. Principal Pattern Sequence (PPS) obtained at the 250 hPa level. (a) PPS1, (b) PPS2, (c) PPS3, and (d) PPS4.

From left to right: day 2, day 1, day 0 . 
the following days, this large upper-level low-pressure system amplifies and moves slowly eastward. On the day of the SACZ occurrence (day 0), this low is located approximately over the southeastern part of the state of Rio Grande do Sul (RS). This meteorological pattern is usually related to a cut-off low whose associated cyclonic circulation generally appears in the middle and upper troposphere (Reboita et al., 2010c; Pinheiro et al., 2017).

\subsection{Geopotential height at $500 \mathrm{hPa}$}

The $500 \mathrm{hPa}$ level represents the middle troposphere and is very important for weather forecasts because the surface systems follow the wind movement at this upper level (Petterssen, 1956; Celemin, 1984; Inness and Dorling, 2013). The PPS analysis obtained six PPSs that explain $91.6 \%$ of the total variance, with the first four PPS representing $85.6 \%$ of this total (Table II). The remaining PPSs were not considered in this study since their explained variances were lower than 5\%. The four PPS are shown in Figure 4.

PPS1 (Fig. 4a) explains $29.1 \%$ of the total variance. It shows a sequence pattern similar to the PPS 1 of $250 \mathrm{hPa}$, but with displacement toward the east. A pronounced long-wave trough is seen with its axis extending northward from the northern part of Argentinean Patagonia to northern Argentina. Ahead of this trough, there is a high-pressure system moving slowly eastward and is usually related to the climatological position of the SASA observed at the surface. Another area of low relative pressure located in northeastern Brazil, probably associated with the CVHL-NB, usually appears more clearly at $250 \mathrm{hPa}$ (Fig. 3a). The frontal trough is observed approximately over RS state and shows strong baroclinicity during the day the SACZ is formed (day 0).

PPS2 (Fig. 4b), with $26.0 \%$ of the total variance, also shows a sequence pattern similar to the PPS2 of $250 \mathrm{hPa}$, where a blocking configuration is evident during the analyzed period. There is a long-wave pattern showing an amplification as it moves slowly to the east, with the ridge advancing southeastward and the trough moving northeastward on the day of the SACZ occurrence (day 0). The long-wave trough is usually associated with a cold front located approximately over the coast of southeastern Brazil.

PPS3 (Fig. 4c) represents $15.9 \%$ of the total variance and also shows a sequence pattern similar to the PPS3 of $250 \mathrm{hPa}$, where the displacement of a frontal trough from the south to the southeast region of Brazil occurs. This upper-level low-pressure system shows rapid amplification over the ocean, which may be associated with cyclogenesis or frontogenesis development at the surface. On the day of the SACZ occurrence (day 0), there is a large area of high pressure behind the frontal trough covering a great part of Argentina, Paraguay, Uruguay, and most of the south region of Brazil, producing strong subsidence in the middle troposphere. Simultaneously, the frontal trough is related to the presence of a frontal system close to the coast of southeastern Brazil.

The last sequence pattern (PPS4) (Fig. 4d) explains $14.6 \%$ of the total variance and shows an atmospheric circulation type associated with a cut-off low, similar to the PPS4 of $250 \mathrm{hPa}$. This upper-level low-pressure system is centered over the southern region of Brazil and the adjacent Atlantic Ocean, which remains practically stationary during the three days.

\subsection{Geopotential height at $850 \mathrm{hPa}$}

The $850 \mathrm{hPa}$ level represents the low troposphere and is also very important for weather forecasts because it is used to detect the position of the wet and dry regions. The winds at this level transport atmospheric water vapor from one place to another contributing to the formation of rain clouds (Petterssen, 1956; Celemin, 1984; Inness and Dorling, 2013).

The PPS analysis yielded seven PPSs that explain $76.5 \%$ of the total variance, with the first four PPSs representing $60.9 \%$ of this total (Table II). The remaining PPSs were not considered here because their series of component loadings presented values smaller than 0.5 (Harman, 1976; Cattell, 1978). The four PPSs are shown in Figure 5.

PPS1 (Fig. 5a) explains $26.1 \%$ of the total variance. It shows a sequence pattern associated with the displacement of a typical frontal trough that advances from Uruguay and northeastern Argentina (day 2) toward southeastern Brazil (day 0). Two days before (day 2) the SACZ episode, a low-pressure system located between northern Argentina and southern Bolivia is observed, probably related to the NAL presence at the surface. With such low pressure and the low-level atmospheric circulation associated, the south part of the southeast region of Brazil is affected by warm and moist air transported from the Amazon 
a)
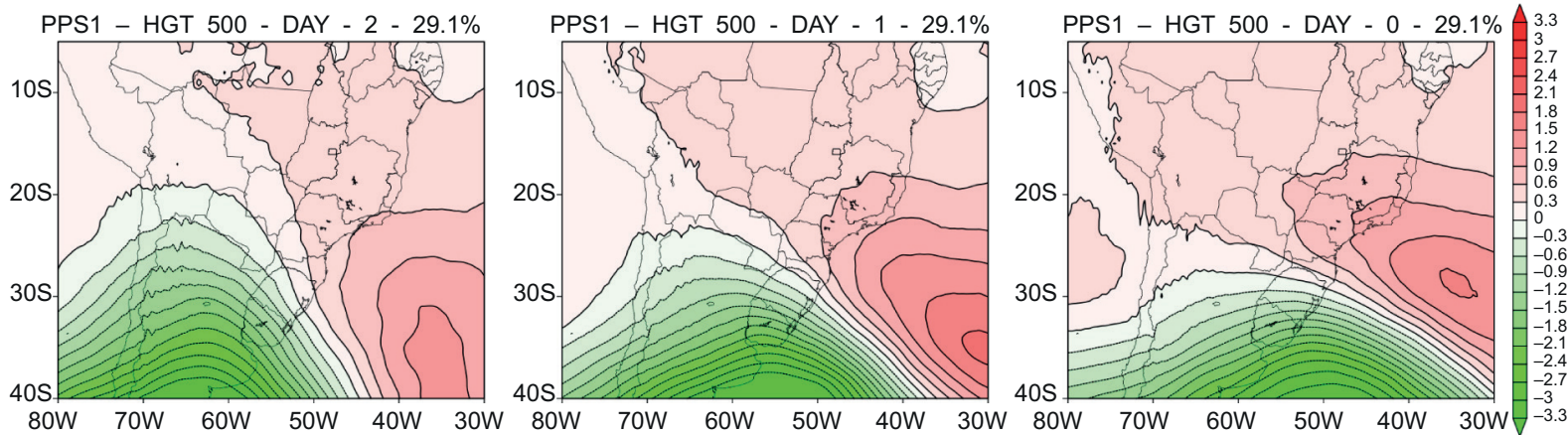

b)

PPS2 - HGT $500-$ DAY - $2-26.0 \%$
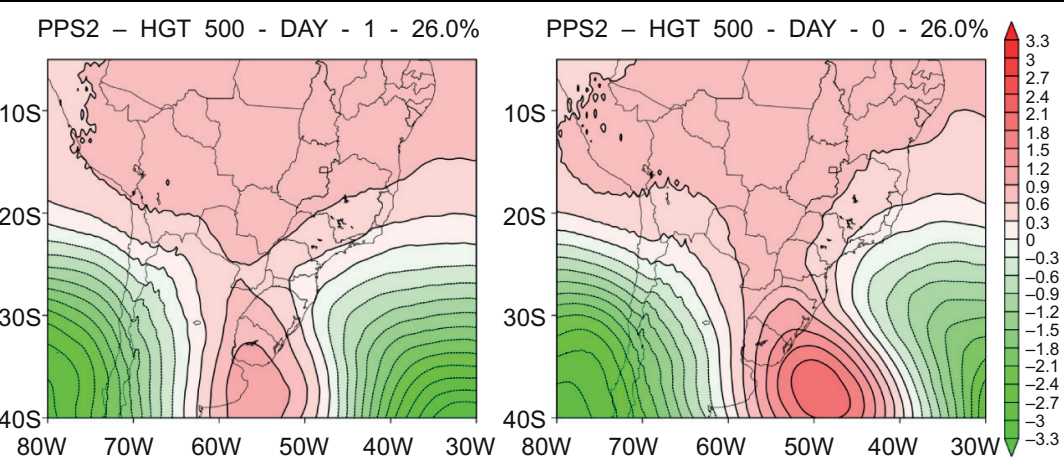

80W 70W 60W 50W 40W 30W

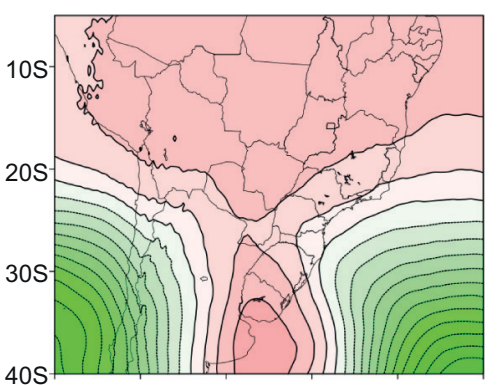

PPS3 - HGT 500 - DAY - 2 - 15.9\%
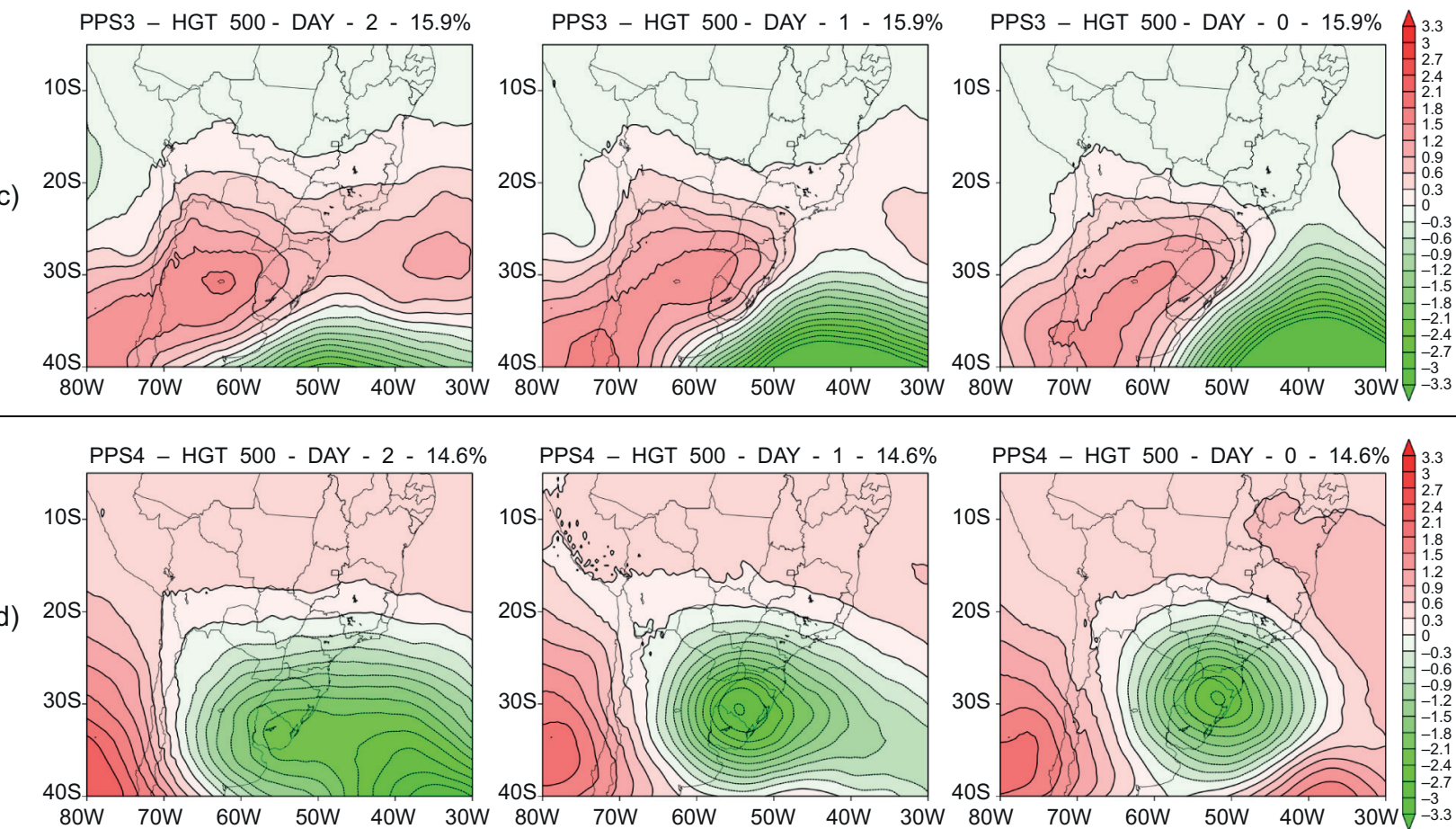

Fig. 4. Principal Pattern Sequence (PPS) obtained at the $500 \mathrm{hPa}$ level. (a) PPS1, (b) PPS2, (c) PPS3, and (d) PPS4. From left to right: day 2, day 1 , day 0 . 

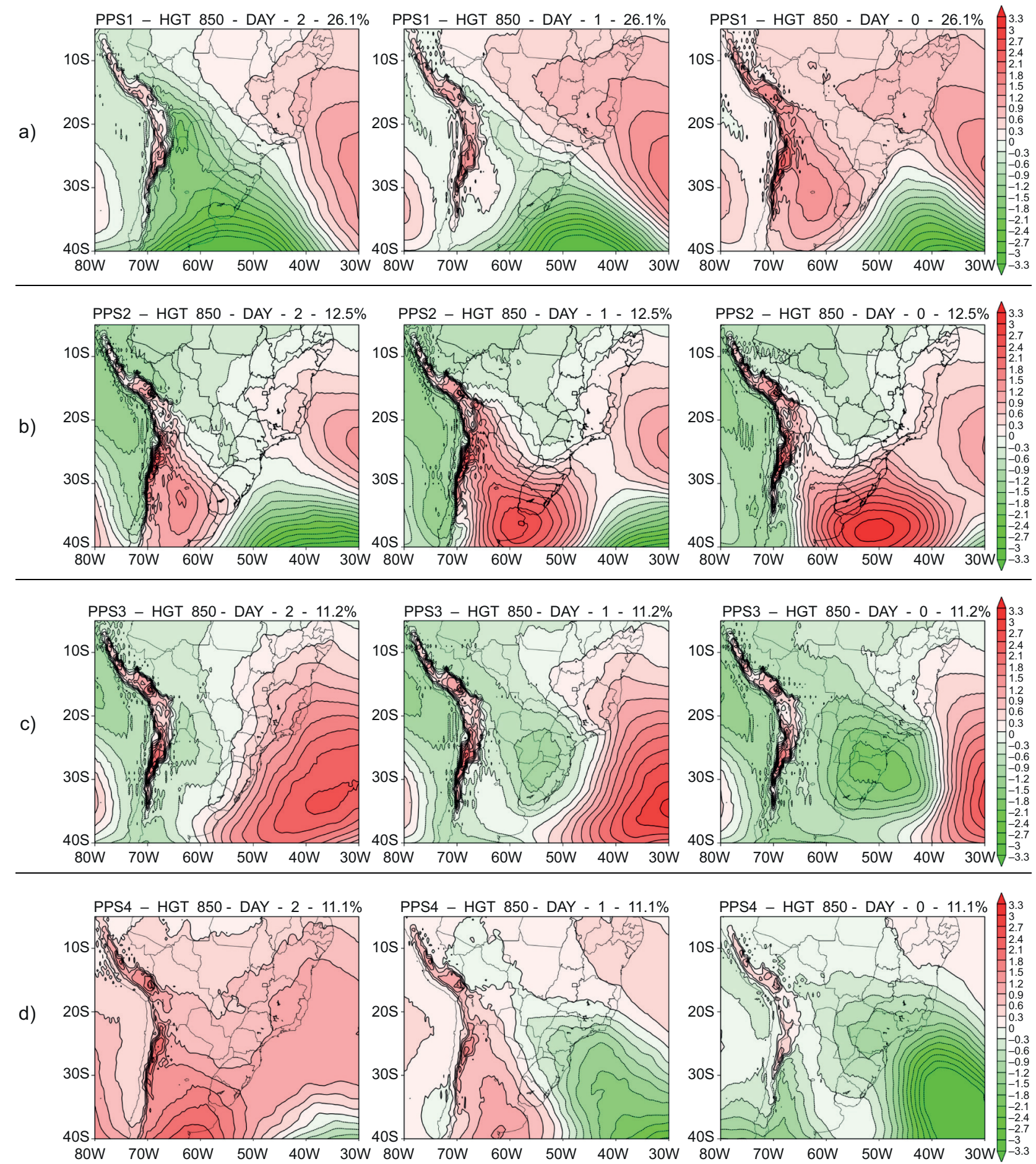

Fig. 5. Principal Pattern Sequence (PPS) obtained at the 850 hPa level. (a) PPS1, (b) PPS2, (c) PPS3, and (d) PPS4. From left to right: day 2, day 1, day 0 . 
basin. Several studies have shown the relationship between low pressure and the flow from Amazonia to the subtropics (e.g., Campetella and Vera, 2002).

PPS2 (Fig. 5b) explains $12.5 \%$ of the total variance. It shows a frontal trough advancing with a slow and oceanic displacement from Santa Catarina (SC) state on day 2 to the Atlantic Ocean near the coast of RJ state during the day of the occurrence of the SACZ (day 0). During the analyzed period, there is a relatively low pressure system represented by an inverted trough over the continent affecting the northern part of the south region and part of the central-west region of Brazil. During day 2 and day 1 , this pattern indicates the occurrence of a northeasterly flow from the Atlantic Ocean to the southeast region of Brazil, and on the SACZ day (day 0), the southeasterly winds intensify the convergence of a moist air mass over the coast of SP and RJ states.

PPS3 (Fig. 5c) explains $11.2 \%$ of the total variance. It shows a sequence pattern related to the developing of a large low-pressure system over the central-south region of Brazil. On day 2 there is an inverted trough between northern Argentina and Uruguay that intensifies and forms a large low-pressure system as it slowly moves eastward during the subsequent days. During the entire analyzed period, a large high-pressure system over the Atlantic Ocean is related to the SASA that slowly moves eastward as the low-pressure intensifies. Thus, a strong horizontal geopotential height gradient between both pressure systems (low-pressure and SASA) is established, producing a significant northeasterly flow over a large part of the south and southeast regions of Brazil on day 2. During the following days, the geopotential height indicates a northwesterly flow over SP and RJ states and over the southern part of MG, which contributes to intensifying the moisture flux convergence over these areas. This atmospheric circulation type at $850 \mathrm{hPa}$ seems to be associated with a weak extratropical cyclone at the surface or with a cut-off low that does not reach the surface. In both cases, an intense advection of warm and moist air from the Amazon region and from the Atlantic Ocean to the southeast region of Brazil was determined to have contributed to this circulation.

The last sequence pattern (PPS4) (Fig. 5d) explains $11.1 \%$ of the total variance and reveals the displacement of a frontal trough that amplifies and intensifies as it moves northeastward over the Atlantic Ocean. On day 1 and during the SACZ day (day 0), a secondary trough over the continent is observed with its axis extending approximately southeastward from MS state to SC and Paraná (PR) states. With such 850-hPa geopotential height field, a great part of the southeast and the southern part of the central-west regions of Brazil are influenced by westerly and northwesterly winds that transport warm and moist air from the Amazon basin. On the other hand, a high-pressure system located over central Argentina advances eastward toward the Atlantic Ocean and weakens over the continent during the SACZ day (day 0). The rapid intensification of the frontal trough over the Atlantic Ocean could be associated with cyclogenesis at the surface.

\subsection{Sea level pressure}

For SLP, we found eight PPSs that explain $80.4 \%$ of the total variance, with the first four PPSs representing $59.1 \%$ of this total (Table II). As was mentioned in the analysis of the $850-\mathrm{hPa}$ geopotential height field, the remaining PPSs were not considered in the analysis since their series of component loadings presented values lower than 0.5 (Harman, 1976; Cattell, 1978). All the PPSs (Fig. 6) obtained at this level have similar configurations to those identified at the $850 \mathrm{hPa}$ level (Fig. 5).

PPS1 (Fig. 6a) explains $18.2 \%$ of the total variance. It shows at day 2 a large high-pressure system related to the SASA, which is positioned at approximately $38^{\circ} \mathrm{S}, 42^{\circ} \mathrm{W}$, i.e., south and west of its average climatological position (Marengo et al., 2012). At the same time, there is a low-pressure area on the continent, extending from the south of the Amazon region towards the north of Argentina that it is probably related to the CHL (Escobar and Seluchi, 2012). During the following days, the low-pressure area moves toward the east/southeast while intensifying and covering a great part of south-central Brazil and the adjacent Atlantic Ocean. At SACZ day (day 0), the low-pressure area is commonly associated with a weak extratropical cyclone or sometimes with a subtropical cyclone (Brasiliense et al., 2018), which contributes to intensify the low-level moisture flux convergence. During ZCAS episodes, it is common to observe relative low-pressure areas (inverted troughs or weak cyclones) located approximately over the 
a)
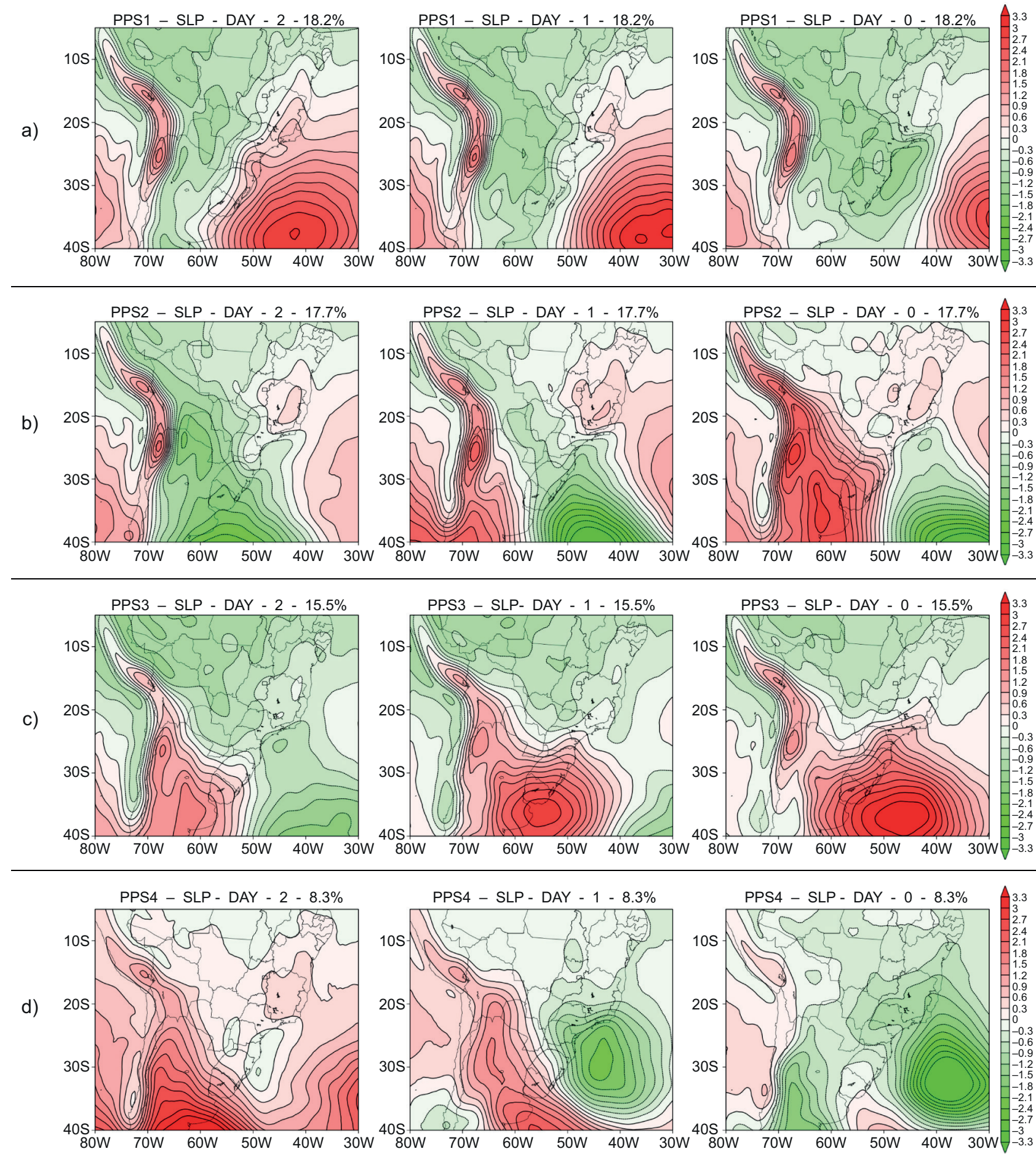

Fig. 6. Principal Pattern Sequence (PPS) obtained at surface level. (a) PPS1, (b) PPS2, (c) PPS3, and (d) PPS4. From left to right: day 2 , day 1 , day 0 . 
ocean off the coast between PR, SP, or RJ states. These low-pressure systems generally form due to the strong latent heat released by the abundant rainfall or by a cyclonic disturbance in the mid-troposphere. Sometimes these cyclones may occasionally exhibit subtropical characteristics (Evans and Braun, 2012; Gozzo et al., 2014; Rocha et al., 2019).

PPS2 (Fig. 6b), with $17.1 \%$ of the total variance, is associated with the typical passage of a cold front during the rainy season in Brazil (Foss et al., 2017; Escobar, 2019; Escobar et al., 2019). Two days before (day 2) of the SACZ episode, the cold front extends approximately between Uruguay and Bolivia. The extratropical cyclone associated with this frontal system is located over the Atlantic Ocean, southward of $40^{\circ} \mathrm{S}$. At the same time, a trough in the Atlantic Ocean with a southwest-northeast orientation between SC and RJ states is present. This trough contributes to the establishment of a continental flow in a northwestern direction over a great part of SP, RJ, and the southern part of MG states. On the day before the SACZ episode (day 1 ), the cold front advances toward the northeast and extends approximately between the southern part of SC state and southeastern Bolivia. The extratropical cyclone associated with the cold front moves to the east and appears over the Atlantic Ocean close to $40^{\circ} \mathrm{S}, 45^{\circ} \mathrm{W}$. On the SACZ day (day 0 ), the cold front is located approximately between SP state and the southern part of MT state. The extratropical cyclone associated with this baroclinic system continues advancing to the east, centering approximately to the south of $40^{\circ} \mathrm{S}$ and close to $35^{\circ} \mathrm{W}$. During the analyzed period, a migratory post-frontal anticyclone is observed entering the continent near $35^{\circ} \mathrm{S}$ on day 2 and reaching the southern part of southeast Brazil during the SACZ day (day 0). On this day, the post-frontal anticyclone is centered close to $35^{\circ} \mathrm{S}, 63^{\circ} \mathrm{W}$; however, the presence of two ridges is evident, with one advancing to the southeast region of Brazil and the other entering to the east of the Andes mountains and extending to the north of Argentina and Bolivia. With this surface atmospheric circulation, the SACZ is established over the southern part of southeastern Brazil, creating a moisture convergence flux from the Amazon region to the Atlantic Ocean, which persists for at least three days. Therefore, the resulting rainfall affects a large portion of the central-west and southeast regions of Brazil.

PPS3 (Fig. 6c) explains $15.5 \%$ of the total variance and also has meteorological characteristics related to a cold front. In this case, the frontal system has a larger amplitude and is more intense than the baroclinic wave of the PPS2. Both the cold front and the migratory anticyclone slowly move to the east, establishing a surface atmospheric circulation similar to a blocking configuration (Sinclair, 1996). This synoptic surface pattern is one of the most frequent weather types observed during the Brazilian rainy season (Escobar, 2019). On day 2, the cold front is located approximately between the south of SP state and the southern part of MS state. The post-frontal anticyclone is situated at the center of Argentina, and it extends over much of this country, Uruguay and most of RS state. On day 1, the post-frontal anticyclone is centered over the Atlantic Ocean at approximately $36^{\circ} \mathrm{S}, 55^{\circ} \mathrm{W}$. The cold front appears over the Atlantic Ocean connected with an inverted trough located over RJ state. The day when the SACZ is configured (day 0), the cold front can be seen over the ocean close to ES state and the south of BA state while the high-pressure system continues to move slowly eastward appearing centered approximately at $37^{\circ} \mathrm{S}, 49^{\circ} \mathrm{W}$. There is an inverted trough over the continent with its axis extending southward from MS state to the western part of PR state and Paraguay during the analyzed period. With this sequence pattern of surface atmospheric circulation, the cold front is positioned further north compared to PPS2. Therefore, the most significant precipitation tends to concentrate between the northern part of southeastern Brazil and the southern part of the northeast region of Brazil.

Finally, PPS4 (Fig. 6d) explains $8.3 \%$ of the total variance and also shows a meteorological situation related to a cyclogenesis process. On day 2 , the extratropical cyclone begins to form over the Atlantic Ocean, off the coast of SC state. During the following days, the cyclone rapidly intensifies and moves toward the east/southeast. On day 1, the cold front appears approximately over the southern part of the southeast region of Brazil, reaching ES and the south of BA states during the SACZ episode (day $0)$. Simultaneously, at day 2 , there is a high-pressure system over the continent located to the southwest 
of the extratropical cyclone and a ridge extending toward the north of Argentina and south of Bolivia. This broad area of high pressure located behind the cold front quickly weakens and remains only over the ocean, to the southwest of the cyclone when the SACZ is formed (day 0). In this case, the surface synoptic chart associated with SACZ events favors the moisture flux convergence and the consequent precipitation concentrated between the southeast and northeast regions of Brazil.

\subsection{Relationship between surface and altitude at- mospheric circulation patterns}

Previous sections presented the PPSs obtained for each atmospheric level. However, we can merge the PPSs to describe the vertical structure of the atmosphere associated with each SACZ pattern. We constructed Table III based on the correlation between the series of component loadings of each PPS identified at each level and on the synoptic and climate knowledge of South America. Finally, we concluded that there are four main atmospheric circulation patterns associated with SACZ episodes (Table III). The four synoptic patterns are cold front (CF), blocking anticyclone (BAn), cut-off low (CL), and cyclogenesis (CG). The $\mathrm{CF}$ and BAn patterns show the same PPS for all the three geopotential height levels $(250,500$, and $850 \mathrm{hP})$. On the other hand, the CL and CG patterns show the same PPS only in the middle and upper troposphere. Then, real atmospheric circulation fields at each analyzed level related to the four atmospheric circulation patterns were selected through the series of component loadings that presented values greater than 0.7 .

Table III. Relationship of PPSs between the four atmospheric levels $(250,500$, and $850 \mathrm{hPa}$, as well as SLP) for each of the four main atmospheric circulation patterns identified during SACZ events.

\begin{tabular}{lcccc}
\hline & $250 \mathrm{hPa}$ & $500 \mathrm{hPa}$ & $850 \mathrm{hPa}$ & SLP \\
\hline CF & PPS 1 & PPS 1 & PPS 1 & PPS 2 \\
BAn & PPS 2 & PPS 2 & PPS 2 & PPS 3 \\
CL & PPS 4 & PPS 4 & PPS 3 & PPS 1 \\
CG & PPS 3 & PPS 3 & PPS 4 & PPS 4 \\
\hline
\end{tabular}

CF: cold front; BAn: blocking anticyclone; CL: cut-off low; CG: cyclogenesis.

\subsubsection{Synoptic patterns}

3.5.1.1 Cold front (CF): Synoptic pattern associated with the advance of a cold front

A real sequence of surface and altitude charts related to a CF pattern is shown in Figure 7, which shows the displacement of a typical cold front during 12:00 UTC on March 20-22, 2014. Each atmospheric level $(250,500$, and $850 \mathrm{hPa}$, as well as SLP) is composed of three frames, corresponding to day 2 in the left, day 1 in the middle, and day 0 (related to the day of SACZ occurrence) in the right.

On day 2 (Fig. 7a), the cold front at the surface is located in the southern part of Buenos Aires province $\left(40^{\circ} \mathrm{S}\right)$ and reaches SP state on the SACZ day (day $0)$, with the post-frontal anticyclone centered over the continent at around $30^{\circ} \mathrm{S}$ (Fig. 7c). In the middle (500 $\mathrm{hPa})$ and upper troposphere $(250 \mathrm{hPa})$, the frontal trough is seen, which is related to the cold front at the surface and becomes deeper as it moves eastward, particularly when it is located over the Atlantic Ocean during the SACZ day (day 0). Two days before the SACZ occurrence (day 2), the 850-hPa geopotential height field shows a northwesterly wind between the northern part of the south and southeastern regions of Brazil, leading to the advection of warm and humid air from the Amazon to southeastern Brazil. This synoptic pattern is similar to the one identified by Escobar (2019) when he carried out a synoptic climatology during the Brazilian rainy season.

\subsubsection{Blocking anticyclone (BAn): Synoptic pat- tern related to blocking situations over the Atlantic Ocean}

A real sequence of surface and altitude charts related to a BAn pattern shows a slow displacement of a cold front with a large post-frontal anticyclone in its wake during 12:00 UTC on February 13-15, 2014 (Fig. 8).

Two days before the SACZ episode (day 2) (Fig. 8a), the cold front is located over RS state with its associated post-frontal anticyclone of $1025 \mathrm{hPa}$ centered over the northern part of Argentinean Patagonia. This high-pressure system moves eastward and is located over the Atlantic Ocean around $40^{\circ} \mathrm{S}, 50^{\circ} \mathrm{W}$ on the SACZ day (day 0) (Fig. 8c) with a central pressure of $1031 \mathrm{hPa}$. During the analyzed period, there is a low-pressure system of $1010 \mathrm{hPa}$ (Fig. 8a) over the continent related to the CHL that usually stands out over northern Argentina, Paraguay, and the southern 

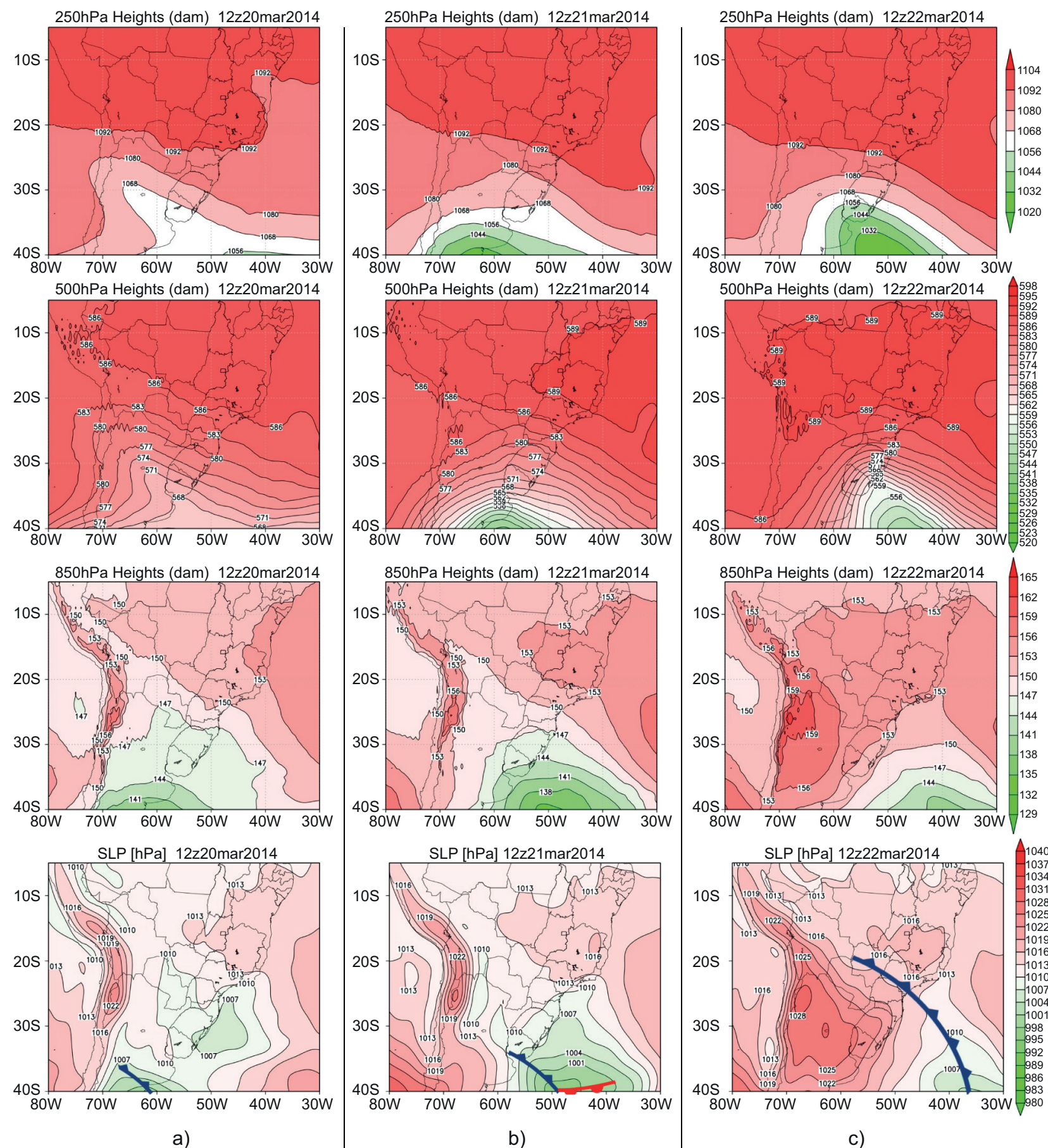

a)

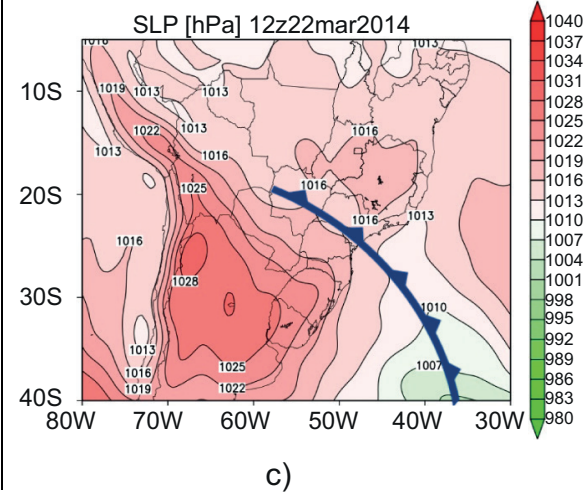

Fig. 7. Real sequence of geopotential height fields at $250,500,850 \mathrm{hPa}$ (in dam), and SLP at surface (top to bottom) related to the CF pattern for March 20-22, 2014. (a) day 2, (b) day 1, and (c) day 0. 

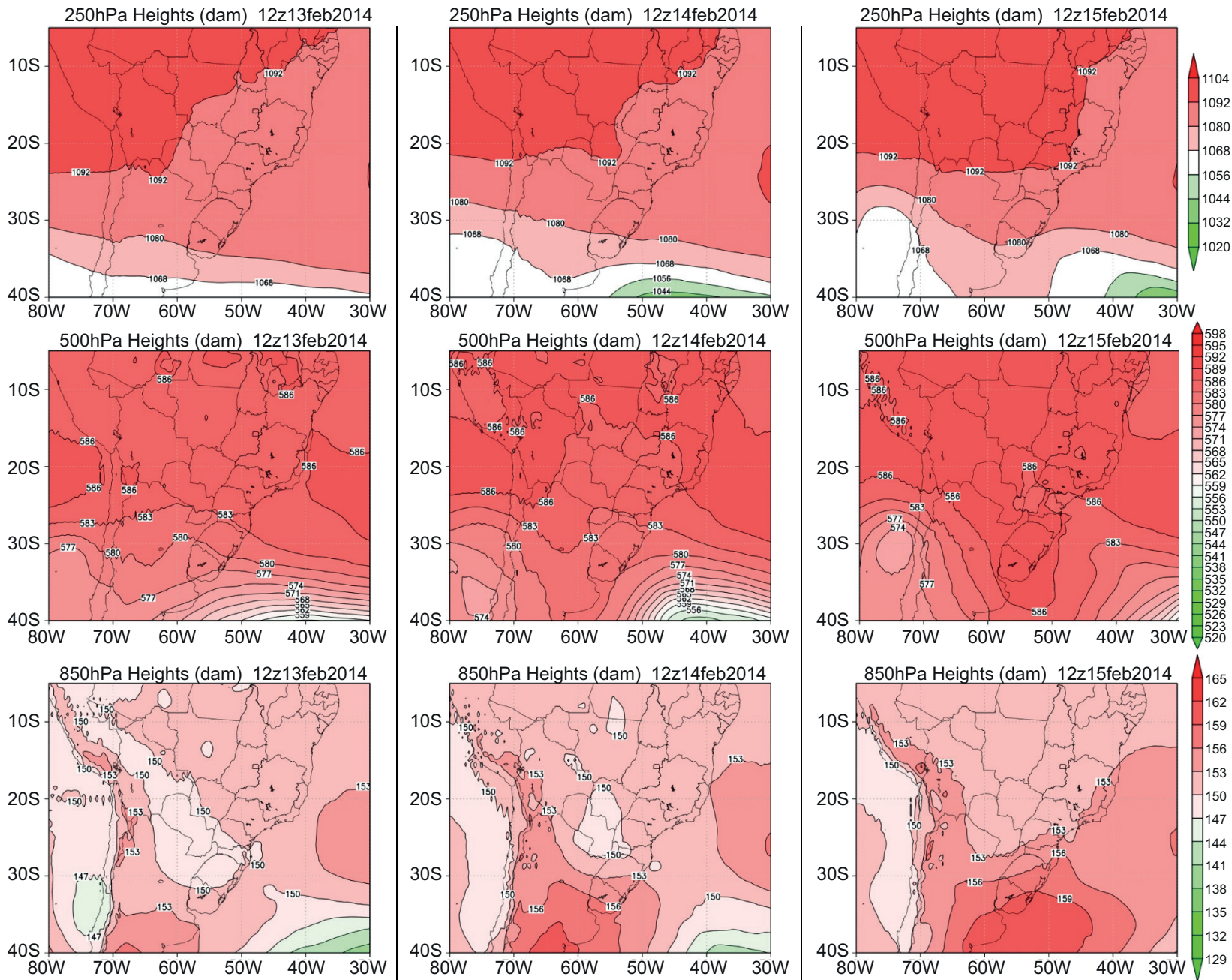

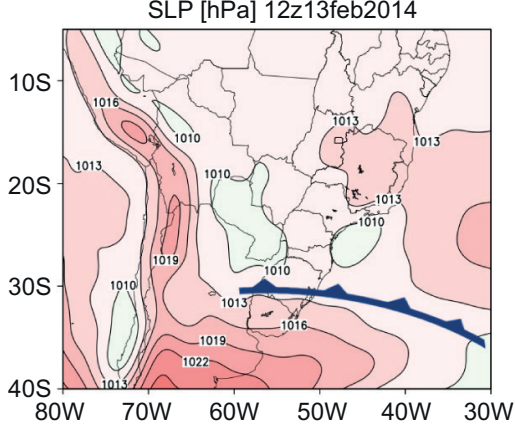

a)

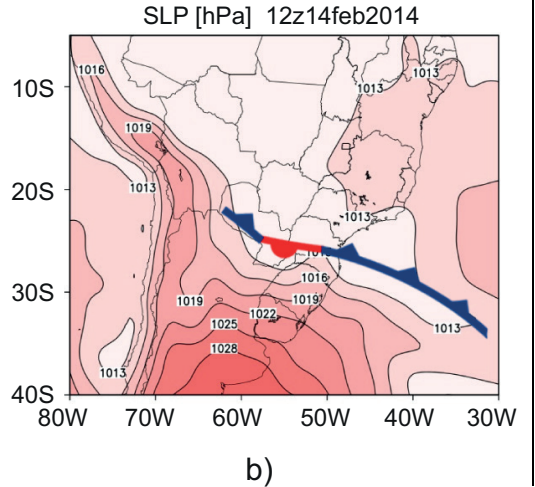

b)

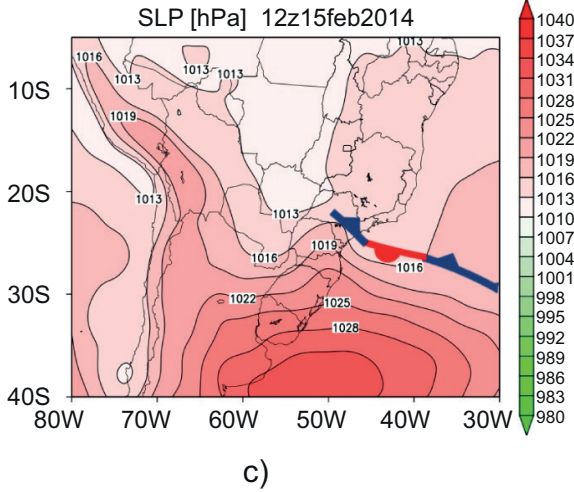

c)

Fig. 8. Real sequence of geopotential height fields at 250,500, and $850 \mathrm{hPa}$ (in dam), and SLP at surface (top to bottom) related to the BAn pattern for February 13-15, 2014. (a) day 2, (b) day 1, and (c) day 0. 
part of MS during the rainy season in Brazil (Escobar and Seluchi, 2012). The mid- and upper-level atmospheric circulations show a long-wave pattern similar to an atmospheric blocking configuration over the Atlantic Ocean. On the SACZ day (day 0) (Fig. 8c), there is a frontal trough with a northwestward extension and a ridge with a southeastward extension. Thus, the blocking is positioned over the Atlantic Ocean around $40^{\circ} \mathrm{S}, 50^{\circ} \mathrm{W}$. During day 2 (Fig. 8a) and day 1 (Fig. 8b), the 850-hPa geopotential height pattern shows a northwesterly flow from the Amazon basin to the southeast region of Brazil due to the presence of the CHL. On the SACZ day (day 0) (Fig. 8c), this atmospheric pattern shows a southeasterly flow from the Atlantic Ocean determined by the cold front close to the coast of SP state. This synoptic pattern is also one of the most frequent during the Brazilian rainy season (Escobar, 2019) and is usually associated with heavy rains along the coast of the southeast region of Brazil (Seluchi and Chou, 2009; Weide-Moura et al., 2013).

\subsubsection{Cut-off low (CL): Synoptic pattern asso- ciated with a cut-off low over the central-south of} Brazil

A real sequence of surface and altitude charts related to a CL pattern shows the slow propagation of a large low-pressure area during 12:00 UTC on December 13-15, 2011 (Fig. 9). The mid and upper levels present a cyclonic vortex approximately between Uruguay and RS state with a cyclonic circulation affecting a large part of southeastern South America. This atmospheric circulation pattern exhibits barotropic behavior due to the low-pressure system, observed over the whole troposphere, being practically stationary and in phase, characterizing a cut-off low with a blocking configuration. The relatively lower temperatures associated with the cyclonic perturbation at the upper levels combined with the higher temperatures at surface contribute to the increase of atmospheric instability, favoring heavy rains accompanied by lightning and thunderstorms. The low-level patterns induce moisture transport from the Atlantic Ocean and the southern part of the north region of Brazil, leading to the precipitation over the central and southern part of southeastern Brazil (Escobar, 2014; Muñoz et al., 2016; Brasiliense et al., 2018). The cut-off low system intensifies and reaches the surface favoring the occurrence of a surface cyclone of $1007 \mathrm{hPa}$ (Fig. 9c) over the Atlantic Ocean, close to the south region of Brazil. This cyclone is usually not frontal and shows subtropical features (Evans and Braun, 2012; Brasiliense et al., 2018; Reboita et al., 2019).

3.5.1.4 Cyclogenesis (CG): Synoptic pattern associated with a cyclogenesis process over the Atlantic Ocean

A real sequence of surface and altitude charts related to a CG pattern corresponds to February 10-12, 2007 when an extratropical cyclone developed over the Atlantic Ocean off the coast between SC and SP states (Fig. 10). The mid and upper levels present a frontal trough with a rapid meridional amplification as it moves northeastward during the analyzed period. At the $250 \mathrm{hPa}$ level, there is also an upper-tropospheric low of 10920 gpm over the Atlantic Ocean, eastern BA state, related to the CVHL-NB that appears over this region during the rainy season in Brazil (Fig. 10a). The 850-hPa geopotential height pattern also features the frontal trough moving northeastward and having a rapid amplification over the Atlantic Ocean since the day before the SACZ occurrence (day 1) (Fig. 10b). The day when the SACZ is formed (day 0) (Fig. 10c), the SLP field shows a cold front extending approximately at the coast of ES state and its associated extratropical cyclone of $1004 \mathrm{hPa}$, located near $31^{\circ} \mathrm{S}$, $30^{\circ} \mathrm{W}$. The post-frontal anticyclone is located around $37^{\circ} \mathrm{S}, 52^{\circ} \mathrm{W}$, generating southeasterly flow over the coast between SC and RJ states. With this synoptic pattern, a convergence of moist air between ES and BA states is established. Therefore, the SACZ episode favors the most significant precipitation occurrence over the northern part of the southeast region of Brazil.

\section{Conclusions}

Synoptic classification of the occurrence of the SACZ during the period 2007-2017 was made in this study to identify the principal modes of variation of the atmospheric circulation at surface and altitude associated with this meteorological system. The atmospheric circulation patterns produced in this study fit very well with the main synoptic types of SACZ recognized by experienced forecasters during the rainy season of Brazil. 

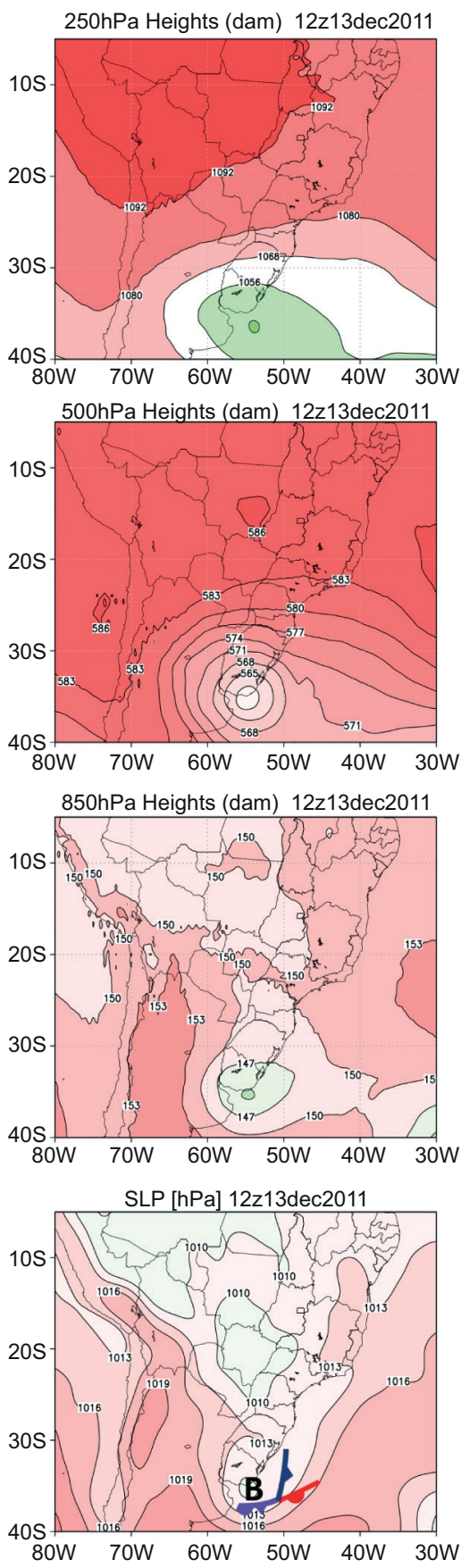

a)
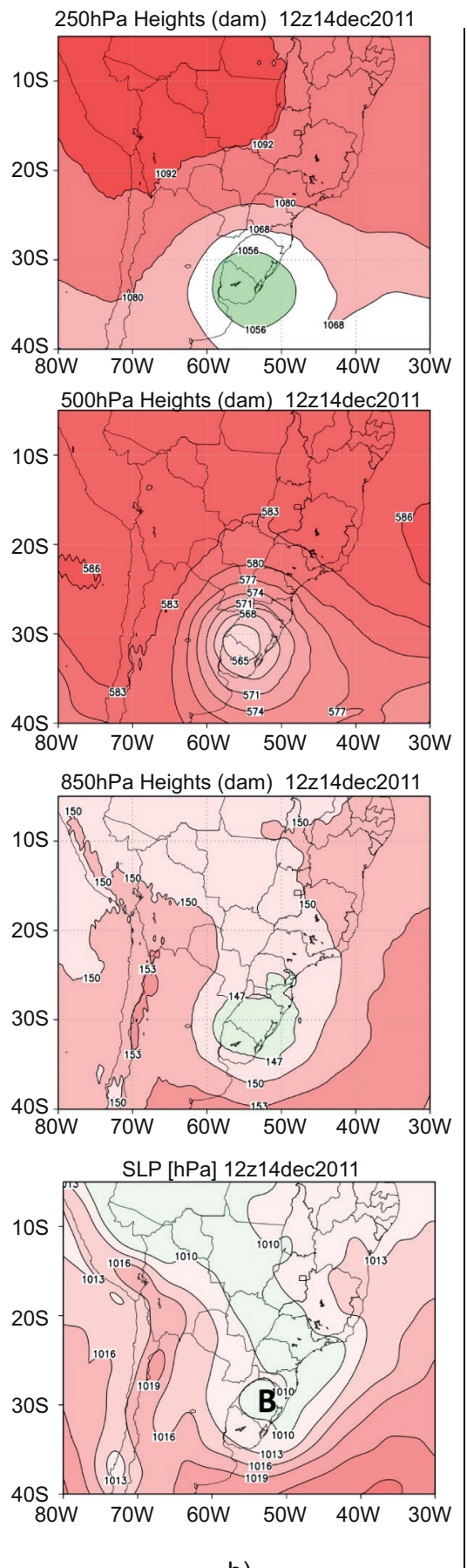

b)
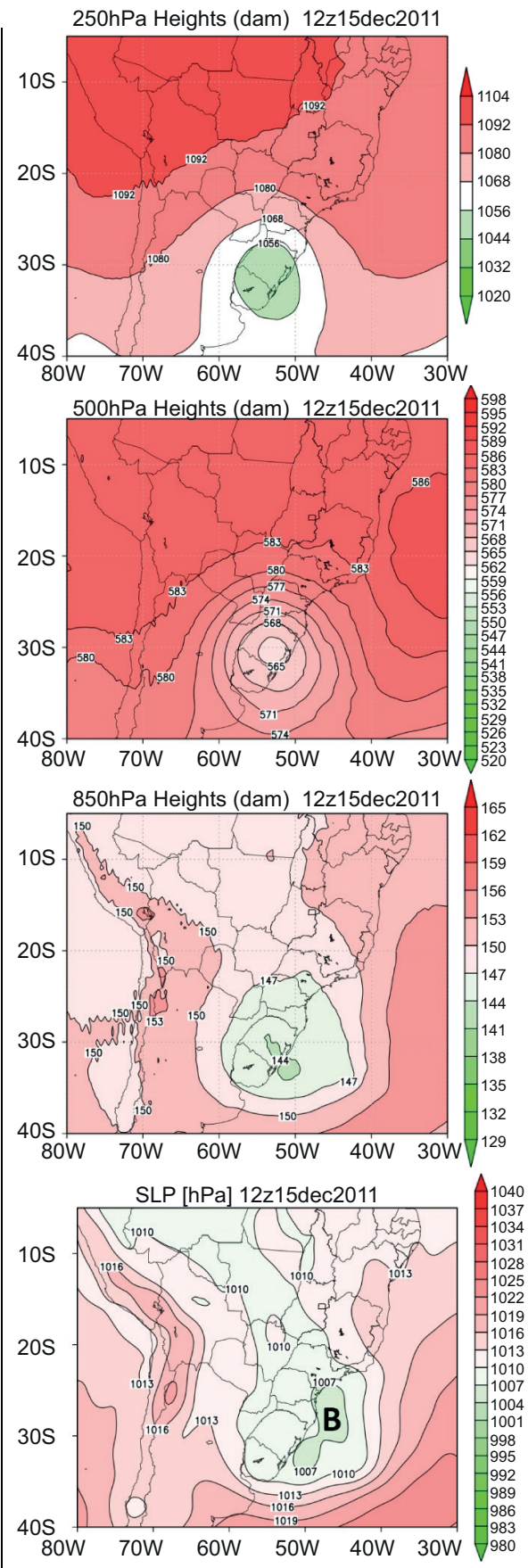

c)

Fig. 9. Real sequence of geopotential height fields at 250, 500, and $850 \mathrm{hPa}$ (in dam), and SLP at surface (top to bottom) related to the CL pattern for December 13-15, 2011. (a) day 2, (b) day 1, and (c) day 0. 

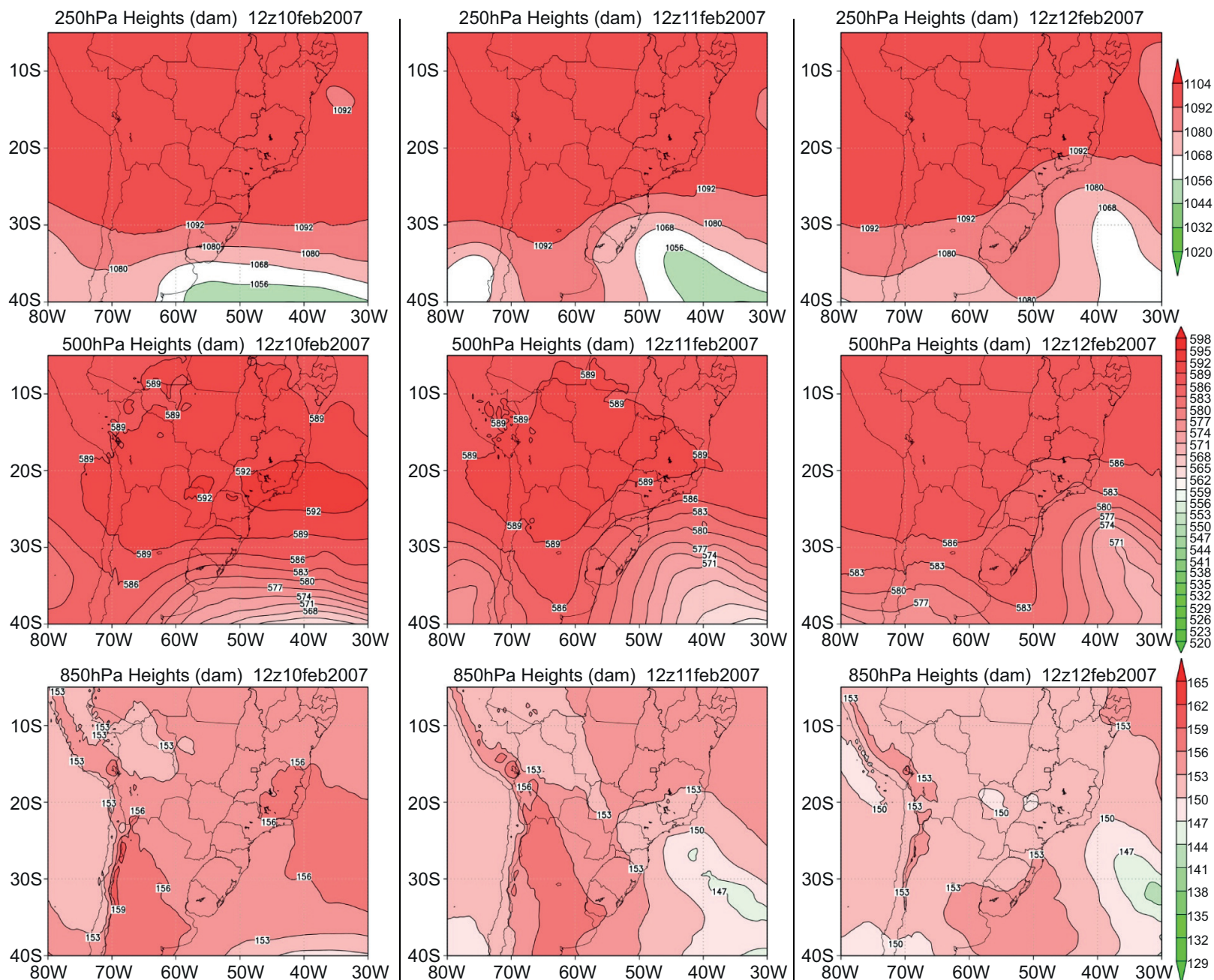

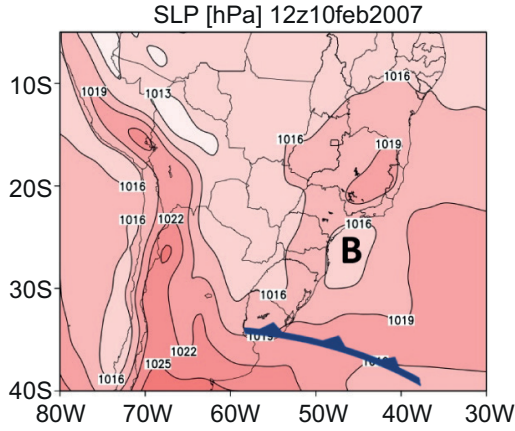

a)

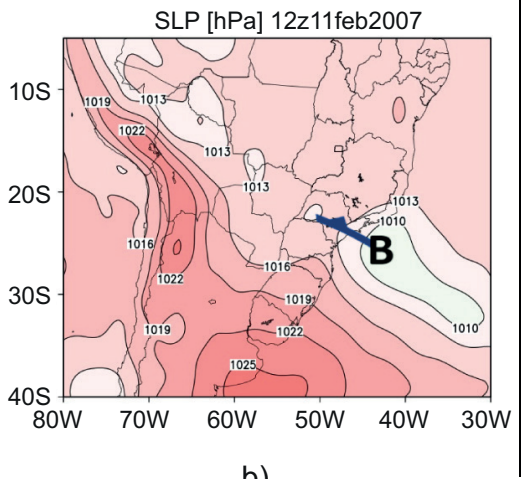

b)
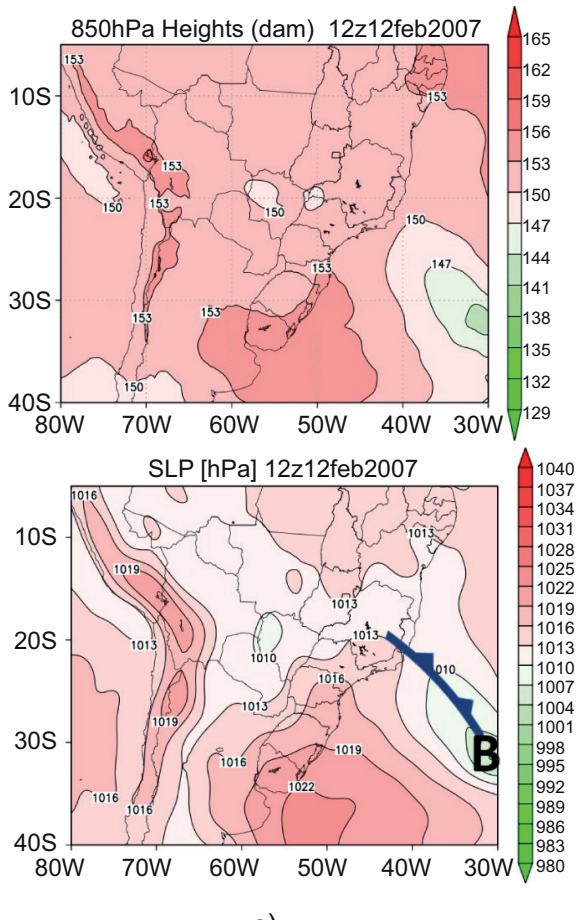

c)

Fig. 10. Real sequence of geopotential height fields at 250, 500, and $850 \mathrm{hPa}$ (in dam), and SLP at surface (top to bottom) related to the CG pattern for February 10-12, 2007. (a) day 2, (b) day 1, and (c) day 0. 
In the middle $(500 \mathrm{hPa})$ and upper $(250 \mathrm{hPa})$ troposphere, the atmospheric circulation shows two patterns (PPS1 and PPS3) related to a typical long wave frontal trough, which amplifies and becomes deeper over the Atlantic Ocean as it begins to move eastward. PPS3 features a more rapid amplification over the ocean than PPS1, favoring a cyclogenetic process at the surface; both patterns also show the influence of the CVHL-NB over the northeast region of Brazil. PPS3 shows the BH positioned over its climatological location. The other patterns (PPS2 and PPS4) are related to an atmospheric circulation similar to a blocking configuration. PPS2 features an intense high-pressure system over the Atlantic Ocean that is practically stationary since the day before the occurrence of the SACZ. On the other hand, PPS4 is associated with a large area of low pressure covering most of the central-south of Brazil that stays stationary during the entire period.

The 850-hPa geopotential height field shows three low-level patterns (PPS1, PPS2, and PPS4) related to the displacement of a frontal trough that reaches southeastern Brazil on the SACZ day. PPS1 features a typical front trough showing a northwesterly humid and warm flow from the Amazon basin for two days before the SACZ episode is established. PPS2 shows a frontal trough with a slow oceanic propagation and a large post-frontal anticyclone located over the Atlantic Ocean. An inverted continental trough also contributes to intensifying the moist and warm air mass convergence one day before over southeastern Brazil. These patterns (PPS1 and PPS2) were also identified at the surface through PPS2 and PPS3, respectively. PPS4 at $850 \mathrm{hPa}$ shows the displacement of a typical frontal system with a meridional propagation, especially from one day before the SACZ episode is established. This pattern was also identified at the surface through the PPS4 that is usually associated with a cyclogenetic process.

The last pattern (PPS3) at $850 \mathrm{hPa}$ is characterized by a large and wide cyclone centered approximately over the central-south of Brazil, which becomes deeper over the Atlantic Ocean as it propagates eastward. The cyclonic circulation related to this low system stays practically stationary during the entire analyzed period. It provides permanent northwesterly winds over southeastern Brazil, resulting in moisture convergence over the area. A similar synoptic pattern was found at the surface by the PPS1 pattern.

The combination of all the levels (surface, lower, mid, and upper levels) identifies four main atmospheric circulation patterns associated with $\mathrm{SACZ}$ episodes. Three of them (CF, BAn and CG) correspond to a cold front moving toward southeastern Brazil with the post-frontal anticyclone moving over the Atlantic Ocean. The last atmospheric circulation pattern (CL) is associated with a cut-off low over the central-south of Brazil.

The CF pattern is related to the typical passage of a cold front during the rainy season in Brazil. At day 2, the cold front is located over central Argentina and enters the coast of SP and RJ states during the day of the SACZ occurrence. At $850 \mathrm{hPa}$, a northwesterly flow over the southern part of the southeast region of Brazil predominates from two days before the occurrence of the SACZ episode. Such evolution of a low-level configuration corresponds to the frontal trough observed in the middle and upper troposphere with the $\mathrm{BH}$ and the CVHL-NB.

The BAn pattern is also associated with a cold front passage, however, with slower displacement concerning the CF pattern. The frontal system moves slowly eastward and stays stationary close to the coast of the northeastern part of SP state and the southern part of RJ state during the SACZ day. This stationary front is connected to a large area of low pressure located over the continent, increasing the moisture convergence and precipitation over the southern part of southeastern Brazil. In the middle and upper troposphere, there is a baroclinic long wave with an associated ridge and trough amplifying and moving slowly to the east, establishing a blocking configuration. With such a synoptic pattern, the post-frontal anticyclone stays stationary for some days, acquiring subtropical characteristics. It means that the SASA is located to the south of its climatological position and the stationary front appears to the north of this high-pressure system.

The CG pattern is also associated with a cold front, though accompanied by a cyclogenetic process over the Atlantic Ocean. The 500-hPa geopotential height pattern shows the baroclinic wave trough becoming deeper and more amplified as it begins to move eastward, particularly when it is positioned over the Atlantic Ocean. The cold front associated 
with this extratropical cyclone is positioned approximately near the coast of ES state. Thus, the convergence zone related to the SACZ episode is located in the northern part of southeastern Brazil.

The last pattern (CL) is related to a cut-off low centered over the central-south of Brazil. The barotropic vertical structure associated with this kind of system shows a low-pressure system that is practically in the same position in the four analyzed levels. At the surface, the cyclone is usually not frontal and presents subtropical features, with a relatively warm core at low levels and a cold core at high levels. This synoptic pattern organizes a convergence zone that induces moisture transport from the Atlantic Ocean and from the southern part of the north region of Brazil to most of southeastern Brazil.

It is important to highlight this paper added two more synoptic patterns associated with SACZ concerning Escobar (2019), when he performed a synoptic classification during the Brazilian rainy season. In addition to this, we also add the description of the meteorological systems in the whole troposphere, considering the low $(850 \mathrm{hPa})$ to upper $(250 \mathrm{hPa})$ levels. Thus, we could identify the principal modes of daily variation of the atmospheric circulation in the whole troposphere associated with SACZ episodes.

Finally, it is noteworthy that the results obtained in this study are useful for weather forecasters working in operational weather centers that have to predict the synoptic patterns of SACZ during the rainy season in Brazil.

\section{Acknowledgments}

The authors thank the National Institute for Space Research (INPE) of Brazil for the synoptic charts and satellite images. We also express our gratitude to the National Center for Environmental Prediction (NCEP) for the reanalysis data and the Brazilian Research Council (CNPq) for financial support ("Edital Universal” grant number 424157/2016-0).

\section{References}

Andrade KM. 2005. Climatologia e comportamento dos sistemas frontais sobre a América do Sul. M.Sc. thesis. Instituto Nacional de Pesquisas Espaciais (INPE), Brazil.
Brasiliense CS, Dereczynski CP, Satyamurty P, Chou SC, Silva Santos VR, Calado RN. 2018. Synoptic analysis of an intense rainfall event in Paraíba do Sul river basin in southeast Brazil. Meteorological Application 25: 66-77. https://doi.org/10.1002/met.1670.

Campetella CM, Vera CS. 2002. The influence of the Andes mountains on the South American low-level flow. Geophysical Research Letters: 29: 7.1-7.4. https://doi. org/10.1029/2002GL015451

Carvalho LMV, Jones C, Liebmann B. 2004. The South Atlantic convergence zone: Intensity, form, persistence, and relationships with intraseasonal to interannual activity and extreme rainfall. Journal of Climate 17 : 88-108. https://doi.org/10.1175/1520-0442(2004)017 \%3C0088:TSACZI\%3E2.0.CO;2

Cattell R. 1978. The scientific use of factor analysis in behavioral and life sciences. Plenum Press, New York and London.

Celemin AH. 1984. Meteorologia prática. Author's edition, Mar del Plata, Argentina.

Compagnucci R, Salles MA. 1997. Surface pressure patterns during the year over southern South America. International Journal of Climatology 17: 635-653. https://doi.org/10.1002/(SICI)10970088(199705)17:6<635::AID-JOC81>3.0.CO;2-B

Compagnucci R, Araneo D, Canziani P. 2001. Principal sequence pattern analysis: A new approach to classifying the evolution of atmospheric systems. International Journal of Climatology 21: 197-217. https://doi. org/10.1002/joc.601

Costa CPW, Satyamurty P. 2016. Inter-hemispheric and inter-zonal moisture transports and monsoon regimes. International Journal of Climatology 17: 4705-4722. https://doi.org/10.1002/joc.4662

Craddock JM, Flood CR. 1969. Eigenvectors for representing the $500 \mathrm{mb}$ geopotential surface over the Northern Hemisphere. Quarterly Journal of the Royal Meteorological Society 95: 576-593. https://doi.org/10.1002/ qj.49709540510

Escobar GCJ, Compagnucci RH, Bischoff SA. 2004. Sequence patterns of $1000 \mathrm{hPa}$ and $500 \mathrm{hPa}$ geopotential height fields associated with cold surges in Buenos Aires. Atmósfera 12: 69-89.

Escobar GCJ, Seluchi ME. 2012. Classificação sinótica dos campos de pressão atmosférica na América do Sul e sua relação com as Baixas do Chaco e do Noroeste Argentino. Revista Brasileira de Meteorologia 27: 365-375. 
Escobar GCJ. 2014. Padrões de circulação em superfície e em 500 hPa na América do Sul e eventos de anomalias positivas de precipitação no estado de Minas Gerais durante o mês de dezembro de 2011. Revista Brasileira de Meteorologia 29: 105-124. https://doi.org/10.1590/ S0102-77862014000100011

Escobar GCJ, Seluchi ME, Andrade K. 2016. Classificação sinótica de frentes frias associadas a chuvas extremas no leste de Santa Catarina (SC). Revista Brasileira de Meteorologia 31: 649-661. https://doi. org/10.1590/0102-7786312314b20150156

Escobar GCJ, Matoso V. 2018. Zona de CONVERGÊNCIA do Atlântico Sul (ZCAS): Definição prática segundo uma visão operacional. In: XX Congresso Brasileiro de Meteorologia. Maceió. Anais do XX Congresso Brasileiro de Meteorologia.

Escobar GCJ. 2019. Classificação sinótica durante a estação chuvosa do Brasil. Anuário do Instituto de Geociências-UFRJ 42: 421-436. https://doi.org/ $10.11137 / 2019 \_2 \_4214436$

Escobar GCJ, Reboita MS, Souza A. 2019. Climatology of surface baroclinic zones in the coast of Brazil. Atmósfera 32: 129-141. https://doi.org/10.20937/ ATM.2019.32.02.04

Evans JL, Braun A. 2012. A climatology of subtropical cyclones in the South Atlantic. Journal of Climate 25: 7328-7340. https://doi.org/10.1175/JCLI-D-11-00212.1

Foss M., Chou S.C. and Seluchi M.E., 2017. Interaction of cold fronts with the Brazilian plateau: A climatological analysis. International Journal of Climatology 37 : 3644-3659. https://doi.org/10.1002/joc. 4945

Gozzo LF, da Rocha RP, Reboita MS, Sugahara S. 2014. Subtropical cyclones over the southwestern South Atlantic: Climatological aspects and case study. Journal of Climate 27: 8543-8562. https://doi.org/10.1175/ JCLI-D-14-00149.1

Green PE, Carroll JD. 1978. Analyzing multivariate data. The Dryden Press, Illinois.

Harman H. 1976. Modern factor analysis. The University of Chicago Press, Chicago IL.

Hoskins BJ, Hodges KI. 2005. New perspectives on the Southern Hemisphere storm tracks. Journal of Climate 18: 4108-4129. https://doi.org/10.1175/JCLI3570.1

Huth R, Beck C, Philipp A, Demuzere M, Ustrnul Z, Cahynová M, Kyselý J, Tveito OT. 2008. Classifications of atmospheric circulation patterns. Recent advances and applications. Trends and Directions in Climate Research 1146: 105-152. https://doi.org/10.1196/annals.1446.019
Inness P, Dorling S. 2013. Operational weather forecasting. Wiley Blackwell, 246 pp.

Jolliffe IT. 1986. Principal components analysis. Springer-Verlag, New York.

Kaiser HF. 1958. The Varimax criterion for analytic rotation in factor analysis. Psychometrika, 23: 187-200.

Kodama YM. 1992. Large-scale common features of subtropical precipitation zones (the Baiu frontal zone, the SPCZ, and the SACZ). Part I: Characteristics of subtropical frontal zones. Journal of the Meteorological Society of Japan 70: 813-835. https://doi.org/10.2151/ jmsj1965.70.4_813

Kousky VE, Gan MA. 1981. Upper tropospheric cyclonic vortices in the tropical South Atlantic. Tellus 36: 538-551. https://doi.org/10.1111/j.2153-3490.1981. tb01780.x

Kousky VE. 1988. Pentad outgoing longwave radiation climatology for the South American sector. Revista Brasileira de Meteorologia 3: 217-231.

Lenters JD, Cook K. 1997. On the origin of the Bolivian high and related circulation features of the South America climate. Journal of the Atmospheric Science 54: 656-677. https://doi.org/10.1175/1520-0469(1997 )054\%3C0656:OTOOTB\%3E2.0.CO;2

McTaggart-Cowan R, Bosart LF, Davis CA, Atallah EH, Gyakum JR, Emanuel KA. 2006. Analysis of Hurricane Catarina (2004). Monthly Weather Review 134: 3029 3053. https://doi.org/10.1175/MWR3330.1

Marengo JA, Liebmann B, Grimm AM, Misra V, Silva Dias PL, Calvalcanti IFA, Carvalho LMV, Berbery EH, Ambrizzi T, Vera CS, Saulo AC, Nogues-Paegle J, Zipser E, Seth A, Alves L. 2012. M. Recent developments on the South American monsoon system. Review. International Journal of Climatology 32: 1-21. https://doi.org/10.1002/joc.2254

Muñoz AG, Goddard L, Mason SJ, Robertson AW. 2016. Cros-time scale interactions and rainfall extreme events in Southeastern South America for the austral summer. Part II: Predictive skill. Journal of Climate 29: 59155934. https://doi.org/10.1175/JCLI-D-15-0699.1

Nogués-Paegle J, Mo KC. 1997. Alternating wet and dry conditions over South America during summer. Monthly Weather Review 125: 279-291. https://doi. org/10.1175/1520-0493(1997)125\%3C0279:AWAD$\mathrm{CO} \% 3 \mathrm{E} 2.0 . \mathrm{CO} ; 2$

Nogués-Paegle J, Mo KC. 2002. Linkages between summer rainfall variability over South America and sea surface temperature anomalies. Journal of Climate 
15: 1389-1407. https://doi.org/10.1175/1520-0442(20 02)015\%3C1389:LBSRVO\%3E2.0.CO;2

Petterssen S. 1956. Weather analysis and forecasting. Vol. I. Motion and motion systems. McGraw-Hill, London, $428 \mathrm{pp}$.

Preisendorfer PW, Zviers FW, Basnett TP. 1981. Foundations of principal component selection rules. Scripps Institute of Oceanography, La Jolla, CA, 192 pp. (SIO Reference Series 81-4).

Pinheiro HR, Hodges KI, Gan MA, Ferreira NJ. 2017. A new perspective of the climatological features of upper-level cut-off lows in the Southern Hemisphere. Climate Dynamics 48: 541-559. https://doi.org/10.1007/ s00382-016-3093-8

Quadro MFL. 1994. Estudo de episódios de Zona de Convergência do Atlântico Sul (ZCAS) sobre a América do Sul. M.Sc. thesis. Instituto Nacional de Pesquisas Espaciais (INPE).

Reboita MS, Gan MA, Rocha RP, Ambrizzi T. 2010a. Regimes de precipitação na América do Sul: Uma revisão bibliográfica. Revista Brasileira de Meteorologia 25: 185-204. https://doi.org/10.1590/S010277862010000200004

Reboita MS, da Rocha RP, Ambrizzi T, Sugahara S. 2010b. South Atlantic Ocean cyclogenesis climatology simulated by regional climate model (RegCM3). Climate Dynamics 35: 1331-1347. https://doi.org/10.1007/ s00382-009-0668-7

Reboita MS, Nieto R, Gimeno L, Rocha RP, Ambrizzi T, Garreaud R, Kruger LF. 2010c. Climatological features of cutoff low systems in the Southern Hemisphere. Journal of Geophysical Research-Atmospheres 115: D17104. https://doi.org/10.1029/2009JD013251

Reboita MS, Marietto, DMG, Souza A, Barbosa M. 2017. Caracterização atmosférica quando da ocorrência de eventos extremos de chuva na região Sul de Minas Gerais. Revista Brasileira de Climatologia 21: 20-37. https://doi.org/10.5380/abclima.v21ii0.47577

Reboita MS, Oliveira DM, Rocha RP, Dutra LMM. 2019. Subtropical cyclone Anita's potential to tropical transition under warmer sea surface temperature scenarios. Geophysical Research Letters 46: 8484-8489. https:// doi.org/10.1029/2019GL083415

Richman, M. 1986. Rotation of principal components. Journal of Climatology 6: 293-335. https://doi. org/10.1002/joc.3370060305

Richman M, Angel J, Gong X. 1992. Determination of dimensionality in eigenanalysis. In: Proceedings of the 5th International meeting on statistical climatology, Toronto, Canada.

Rocha RP, Reboita MS, Gozzo LF, Dutra LMM, Jesus EM. 2019. Subtropical cyclones over the oceanic basins: a review. Annals of the New York Academy of Sciences 1436: 138-156. https://doi.org/10.1111/nyas. 13927

Rosa MB, Satyamurty P, Ferreira NJ, Silva LT. 2019. A comparative study of intense surface cyclones off the coast of southeastern Brazil and Mozambique. International Journal of Climatology 39: 3523-3542. https:// doi.org/10.1002/joc.6036

Saha S, Moorthi S, Pan H, Wu X, Wang J, Nadiga S, Tripp P, Kistler R, Woollen J, Behringer D, Liu H, Stokes D, Grumbine R, Gayno G, Wang J, Hou Y, Chuang H, Juang HH, Sela J, Iredell M, Treadon R, Kleist D, Delst PV, Keyser D, Derber J, Ek, M, Meng J, Wei H, Yang R, Lord S, van den Dool H, Kumar A, Wang W, Long C, Chelliah M, Xue Y, Huang B, Schemm J, Ebisuzaki W, Lin R, Xie P, Chen M, Zhou S, Higgins W, Zou C, Liu Q, Chen Y, Han Y, Cucurull L, Reynolds RW, Rutledge G, Goldberg M. 2010. The NCEP Climate Forecast System Reanalysis. Bulletin of the American Meteorological Society 91: 1015-1057. https://oi. org/10.1175/2010BAMS3001.1

Saha S, Moorthi S, Wu X, Wang J, Nadiga S, Tripp P, Behringer D, Hou Y, Chuang H, Iredell M, Ek M, Meng J, Yang R, Mendez MP, van den Dool H, Zhang Q, Wang W, Chen M, Becker E. 2014. The NCEP Cimate Forecast System Version 2. Journal of Climate 27: 2185-2208. https://doi.org/10.1175/ JCLI-D-12-00823.1

Satyamurty P, Nobre CA, Silva Dias PL. 1998. South America. In: Meteorology of the Southern Hemisphere (Karoly DJ, Vincent DG, Eds.). American Meteorological Society, 119-139. (Meteorological Monographs 27).

Satyamurty P, Rosa MB. 2020. Synoptic climatology of tropical and subtropical South America and adjoining seas as inferred from geostationary operational environmental satellite imagery. International Journal of Climatology 40: 378-399. https://doi.org/10.1002/ joc. 6217

Seluchi M, Marengo J. 2000. Tropical-mid latitude exchange of air masses during summer and winter in South America: Climatic aspects and extreme events. International Journal of Climatology 20: 1167-119. https://doi.org/10.1002/10970088(200008)20:10\%3C1167::AID-JOC526\%3E3. $0 . \mathrm{CO} ; 2-\mathrm{T}$ 
Seluchi ME, Saulo C, Nicolini M, Satyamurty P. 2003. The Northwestern Argentinean Low: A study of two typical events. Monthly Weather Review 131: 2361-2378. https://doi.org/10.1175/1520-0493(2003)131<2361:TNALAS $>2.0 . \mathrm{CO} ; 2$

Seluchi ME, Chou SC. 2009. Synoptic patterns associated with landslide events in the Serra do Mar, Brazil. Theoretical and Applied Climatology 98: 67-77. https:// doi.org/10.1007/s00704-008-0101-x

Silva JP, Reboita MS, Escobar GCJ. 2019. Caracterização da zona de convergência do Atlântico Sul em campos atmosféricos recentes. Revista Brasileira de Climatologia 15: 355-377. https://doi.org/10.5380/abclima. v25i0.64101

Simmonds I, Keay K. 2000. Mean Southern Hemisphere extratropical cyclone behavior in the 40-year NCEP-NCAR reanalysis. Journal of Climate 13: 873-885. https://doi. org/10.1175/ 1520-0442(2000)013,0873:MSHECB. 2.0.CO;2

Sinclair MR. 1996. A climatology of anticyclones and blocking for the Southern Hemisphere. Month- ly Weather Review 124: 245-263. https://doi. org/10.1175/1520-0493(1996)124<0245:ACOAAB> 2.0.CO;2

Taljaard JJ. 1972. Synoptic meteorology of the Southern Hemisphere. In: Meteorology of the Southern Hemisphere (Karoly DJ, Vincent DG, Eds.). American Meteorological Society, 139-213. (Meteorological Monographs 27).

Vera CS, Higgins W, Amador J, Ambrizzi T, Garreaud R, Gochis D, Gutzler D, Lettenmaier D, Marengo JA, Mechoso CR, Nogues-Paegle J, Silva Dias PL, Zhang C. 2006. Toward a unified view of the American monsoon systems. Journal of Climate 19: 4977-5000. https://doi.org/10.1175/JCLI3896.1

Weide-Moura CR, Escobar GCJ, Andrade KM. 2013. Padrões de circulação em superfície e altitude associados a eventos de chuva intensa na região metropolitana do Rio de Janeiro. Revista Brasileira de Meteorologia 28: 267-280. https://doi.org/10.1590/ S0102-77862013000300004 